UNIVERSIDADE DE SÃO PAULO

INSTITUTO DE FÍSICA DE SÃO CARLOS

DANIELE FERNANDA CHIARELLI GONÇALVES

Minimização da estrutura da DisBa-01, uma desintegrina com potenciais atividades anti-trombótica e anti-metastática

São Carlos

2008 
DANIELE FERNANDA CHIARELLI GONÇALVES

\section{Minimização da estrutura da DisBa-01, uma desintegrina com potenciais atividades anti-trombótica e anti-metastática}

Dissertação apresentada ao Instituto de Física de São Carlos da Universidade de São Paulo, como parte dos requisitos para obtenção do título de Mestre em Ciência- Física Aplicadaárea de concentração: Física Biomolecular.

Orientadora: Profa. Dra. Dulce Helena Ferreira de Souza 
AUTORIZO A REPRODUÇÃO E DIVULGAÇÃO TOTAL OU PARCIAL DESTE TRABALHO, POR QUALQUER MEIO CONVENCIONAL OU ELETRÔNICO, PARA FINS DE ESTUDO E PESQUISA, DESDE QUE CITADA A FONTE.

Ficha catalográfica elaborada pelo Serviço de Biblioteca e Informação IFSC/USP

Gonçalves, Daniele Fernanda Chiarelli

Minimização da estrutura da Dis $B a-01$, uma desintegrina com potenciais atividades anti-trombótica e anti-metastática / Daniele FernandaChiarelli Gonçalves; orientador Dulce Helena Ferreira de Souza.--São Carlos, 2008.

$70 \mathrm{p}$.

Dissertação (Mestrado -Programa de Pós-Graduação em Ciências. Área de concentração: Física Aplicada: opção Física Biomolecular) - Instituto de Física de São Carlos da Universidade de São Paulo.

1. Metaloprotease, 2.Desintegrina. 3.DisBa-01. 4. Bothrops alternatus. 5. Câncer. I. Título. 


\section{FOLHA DE APROVAÇÃO}

Daniele Fernanda Chiarelli Gonçalves

Dissertação apresentada ao Instituto de Física de São Carlos da Universidade de São Paulo para obtenção do título de Mestre em Ciências. Área de Concentração: Física Aplicada - Opção: Fisica Biomolecular.

Aprovada em: 27/03/2008

Comissão Julgadora

Profa. Dra. Dulce Helena Ferreira de Souza Instituição: DQ/UFSCar

Assinatura

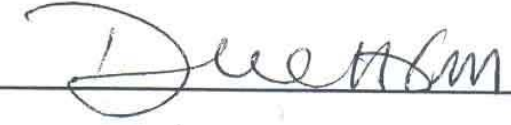

Prof. Dr. Oscar Henrique Pereira Ramos Instituição: Instituto Butantan

Assinatura

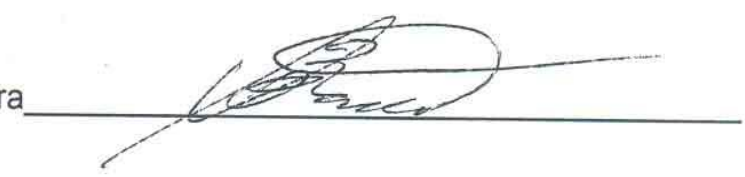

Profa. Dra. Maria Auxiliadota Morim Santos 


\section{DEDICATÓRIA}

A minha família pela dedicação e todo incentivo. 


\section{AGRADECIMENTOS}

À Profa. Dra. Dulce Helena Ferreira de Souza, pela orientação, apoio, compreensão, amizade e oportunidade para desenvolver este trabalho;

Ao Prof. Otávio H. Thiemann, pelo apoio e confiança;

À Profa. Heloísa Selistre de Araújo, pelas dicas, apoio, incentivo e por permitir a realização de parte do trabalho em seu laboratório;

Aos amigos, colegas e técnicos do grupo de cristalografia e biofísica do IFSC, pelo auxílio, cooperação e por proporcionarem um bom convívio;

Aos amigos do laboratório do IFSC, Ana, Amanda, Carol, Carol Hoff, Karime, Livia, João, Wanius, Mário, Aline, Natália, Caqui, Marta e Maria pela ajuda, conversas e amizade;

Aos amigos do laboratório da UFSCar, Barbie, Pat, Bianca, Ariele, Priscila, Ana e Nabor pelo convívio, amizade e boas risadas;

Às meninas do laboratório da Helô, Márcia, Carmem, Milena, Thaíssa, Gisele, Ju, Aline, Rita e Carol pelo auxílio nos experimentos, conversas e descontração;

A Mônica pelo auxílio na realização de alguns experimentos;

As minhas amigas Bia e Carla, sempre presentes, pela ajuda, amizade e carinho;

Em especial a minha família, meus pais, Ivan, meus avós, por todo amor e incentivo;

Ao CNPq pela ajuda financeira para este trabalho. 


\section{RESUMO}

A DisBa-01, uma desintegrina RGD recombinante ainda não isolada do veneno de Bothrops alternatus, exibe alta afinidade pela integrina $\alpha_{\mathrm{IIb}} \beta_{3}$, contribuindo para inibição da agregação plaquetária (RAMOS, 2005). DisBa-01 possui também atividades anti-trombótica e antimetastática comprovadas in vivo (Ramos, 2005). A fim de obter moléculas menores mantendo as atividades da Dis $B a-01$, dois mutantes estão em estudo. Moléculas chamadas Dis $B a(\Delta 1$ 32) e $\operatorname{Dis} B a(\Delta 1-36)$ apresentam 32 e 36 resíduos a menos que a Dis $B a-01$, respectivamente, na região N-terminal. Oligonucleotídeos foram construídos e os DNAs foram amplificados por PCR utilizando o plasmídeo pET28a-Dis $B a-01$ como o molde. Os produtos de PCR foram clonados no vetor de expressão pET32a. Análises das seqüências revelaram que os genes e sua fase de leitura estavam completamente corretos. Os plasmídeos recombinantes foram introduzidos em linhagem BL21 (DE3) de E.coli. Os plasmídeos recombinantes foram induzidos com $0,3 \mathrm{mM}$ de IPTG a expressar as proteínas em fusão com a tiorredoxina. As proteínas foram expressas na forma solúvel e com massa molecular coincidente com a previsão. As proteínas de fusão foram purificadas por cromatografia de afinidade em resina de níquel e clivadas com a enzima enteroquinase. As amostras clivadas foram purificadas por cromatografia de filtração a gel. Os passos de purificação e clivagem foram analisados por SDS-PAGE e reação de immunoblotting utilizando o anticorpo anti-Echistatin. Testes de inibição da adesão celular, usando células de melanoma de camundongo B16F10 ricas em integrina $\alpha \mathrm{V} \beta 3$, mostraram que a $\operatorname{Dis} B a(\Delta 1-32)$ e a $\operatorname{Dis} B a(\Delta 1-36)$ são capazes de inibir, aproximadamente, $70 \%$ da adesão celular, um resultado semelhante ao encontrado para a molécula de Dis $B a-01$. Portanto, as duas moléculas mutantes da DisBa-01 obtidas apresentaram atividades que podem ser exploradas no desenho de novos medicamentos contra câncer.

Palavras-chave: Metaloprotease. Desintegrina. DisBa-01. Bothrops alternatus. Câncer. 


\begin{abstract}
Dis $B a-01$, a recombinant RGD-disintegrin still not isolated from $B$. alternatus venom exhibits high affinity for $\alpha_{\mathrm{II}} \beta_{3}$ integrin, contributing for the inhibition of platelet aggregation (Ramos, 2005). Dis $B a-01$ possesses also antithrombotic and antimetatatic activities in vivo (Ramos, 2005). In order to obtain shorter molecules maintaining activities of DisBa-01 two mutants were studied. Molecules called Dis $B a \Delta(1-32)$ and Dis $B a \Delta(1-36)$ have 32 and 36 residues unless Dis $B a-01$, respectively, in the N-terminal region. Oligonucleotides were designed, the DNAs were amplified by PCR using pET28a-DisBa-01 vector as the template and PCR products were cloned into expression vector pET32a. Sequence analysis showed that the reading frames were completely correct. The recombinant plasmids were introduced into BL21(DE3) E.coli strain. The recombinant plasmids were induced with IPTG to express the proteins in fusion with thioredoxin. Proteins were expressed in a soluble form and with molecular mass coincident with prediction. Fusion proteins were purified by affinity chromatography in nickel resin and cleaved with enterokinase enzyme. Samples of cleavage were purified by the gel filtration chromatography. Purification and cleavage steps were analyzed by SDS-PAGE and immunoblotting reaction using anti-Echistatin antibody. Test of cell adhesion inhibition, using cells from mice B16F10 melanoma, which are rich in integrin $\alpha \mathrm{V} \beta 3$, showed that $\operatorname{Dis} B a(\Delta 1-32)$ and $\operatorname{Dis} B a(\Delta 1-36)$ are able to inhibit approximately $70 \%$ of cell adhesion. Therefore, both DisBa-01 mutant molecules obtained in this work present activities that can be explored in the design of new medicines against cáncer.
\end{abstract}

Keywords: Metalloprotease. Disintegrin. DisBa-01. Bothrops alternatus. Cancer. 


\author{
ABREVIATURAS \\ ADAMs - A Disintegrin And Metalloprotease \\ ADP- Adenosina difosfato \\ Anvisa- Agência Nacional de Vigilância Sanitária \\ BSA - Bovine Serum Albumine \\ BCA- Bicinchoninic Acid \\ cDNA - Complementary DNA \\ CMFDA- 5-chloromethylfluorescein diacetate \\ DNA- Deoxyribonucleic acid \\ dNTP- desoxinucleotídeos trifosfatados \\ E. coli-Escherichia coli \\ ECM- Extracelullar Matrix \\ EDTA- Ácido Etienodiaminotetraacético \\ EGF- Epidermal Growth Factor \\ HEPES- ácido 4-(2-Hidroxietil)-1-piperazinoetanosulfônico \\ KDa- KiloDaltons \\ KTS- resíduos de aminoácidos lisina, treonina e serina \\ ICAMs- Intercellular Adhesion Molecules \\ $\mathrm{IC}_{50^{-}}$Inibição do Crescimento em 50\% \\ IECA-Angiotensin-converting enzyme inhibitors \\ IPTG- isopropil- $\beta$-D-tiogalactopiranosídeo \\ LB- meio de cultura de bactérias (Luria Bertani) \\ MLD- resíduos de aminoácidos metionina, leucina e aspartato \\ pb- pares de base \\ PBS- Phosphate Buffered Saline \\ PCR- Polymerase Chain Reaction \\ P\&D- Pesquisa e Desenvolvimento \\ RGD- resíduos de aminoácidos arginina, glicina e aspartato \\ RMN- Ressonância Magnética Nuclear \\ SECD- resíduos de aminoácidos serina, ácido glutâmico, cisteína e aspartato \\ RNAs- Ribonucleic Acids \\ Rpm- Rotações por minuto \\ SDS-PAGE- Sodium Dupdecyl Sulfate - Polyacrilamide Gel Electrophoresis \\ SVMPs- Snake Venom Metalloproteinases \\ TAE- tampão Tris Acetato EDTA \\ TBS- Tris Buffered Saline \\ VCAM- Vascular Cell Adhesion Molcule \\ VEGF- Vascular Endothelial Growth Factor
}




\section{LISTA DE FIGURAS}

Figura 1- B. alternatus (urutu-cruzeiro) 13

Figura 2 - Organização dos domínios de ADAMs e SVMPs 15

Figura 3 - Representação esquemática da estrutura das subunidades $\alpha$ e $\beta$ de 18 integrina

Figura 4 - Análise de múltiplas seqüências de polipeptídeos selecionados de 21 diferentes subfamílias de desintegrinas

Figura 5 - $\quad$ Estruturas de desintegrinas pequenas, determinadas por RMN 23

Figura 6 - Estrutura tridimensional do segmento extracelular da integrina $\alpha \mathrm{V} \beta 3 \mathrm{em} \quad 27$ complexo com um peptídeo cíclico apresentando o motivo RGD

Figura 7 - Moléculas da classe dos antagonistas dos receptores da glicoproteína 30 GPIIb/IIIa: (A) eptifibatide e (B) tirofiban

Figura 8 - Seqüência de nucleotídeos e aminoácidos pDis $B a-01$

Figura 9 - $\quad$ Modelo do complexo $\alpha \mathrm{V} \beta 3$-Dis $B a 01$ : aspecto da interação geométrica 32 entre a DisBa-01(vermelho) e a subunidade $\alpha$ do receptor (branco) e subunidade $\beta$ (azul)

Figura 10 - Programa utilizado nas reações de PCR para obtenção dos DNAs DisBa 36 $(\Delta 1-32)$ e $\operatorname{DisBa}(\Delta 1-36)$

Figura 11 - Mapa do vetor pET 32a (+), da Novagen 37

Figura 12 - Análise por PCR de colônia dos transformantes com os DNAs pDisBa $(\Delta 43$ 1-32) e $\mathrm{pDisBa}(\Delta 1-36)$ em gel de agarose $1 \%$

Figura 13 - Análise de restrição dos plasmídeos $\operatorname{pDisBa}(\Delta 1-32)$ e pDisBa $(\Delta 1-36) 43$ em gel de agarose $1 \%$

Figura 14 - Seqüência de nucleotídeos e aminoácidos deduzido a partir do $\operatorname{pDisBa}(\Delta 44$ 1-32)

Figura 15 - Seqüência de nucleotídeos e aminoácidos deduzido a partir do $\operatorname{pDisBa}(\Delta 44$ 1-36)

Figura 16 - Análise da expressão e purificação em resina de níquel das proteínas 45 $\operatorname{DisBa}(\Delta 1-32)$ e $\operatorname{DisBa}(\Delta 1-36)$ em gel SDS $15 \%$.

Figura 17 - Perfil cromatográfico da purificação da $\operatorname{DisBa}(\Delta 1-36)$ em coluna de gel 46 filtração (Superdex-75).

Figura 18 - Análise da Purificação da proteína DisBa ( $\Delta$ 1-36) em coluna Superdex 46 75 em gel de tricina

Figura 19 - Perfil cromatográfico da purificação da DisBa ( $\Delta$ 1-32) em coluna de gel 47 filtração (Superdex-75)

Figura 20 - Análise da Purificação da proteína DisBa ( $\Delta 1$-36) em coluna Superdex 7547 em gel de tricina

Figura 21 - Análise de Dot blot da ligação do anticorpo anti- anti-Dis $B a-01$ com as 47 proteínas $\operatorname{DisBa}(\Delta 1-32)$ e DisBa $(\Delta 1-36)$ e Dis $B a-01$

Figura 22 - Análise da inibição da adesão de células B16F10 à vitronectina pela 48 $\operatorname{DisBa}(\Delta 1-32)$ e $\operatorname{DisBa}(\Delta 1-36)$

Figura 23 - Pontes disulfeto previstas para as moléculas DisBa-01, DisBa $(\Delta 1-32)$ e 53 $\operatorname{DisBa}(\Delta 1-36)$ 


\section{SUMÁRIO}

1.INTRODUÇAO

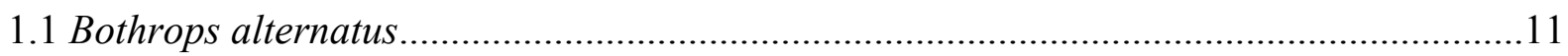

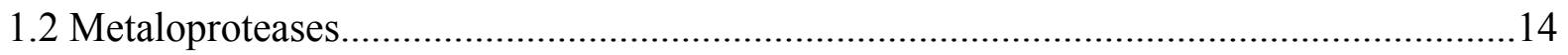

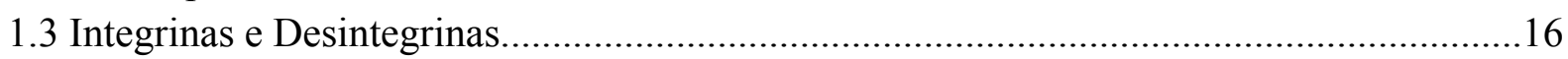

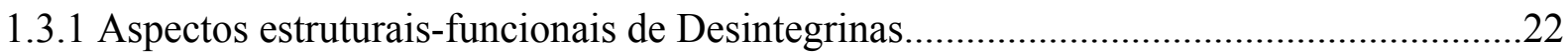

1.4 Desenvolvimento de novos fármacos derivados de moléculas de desintegrinas................28

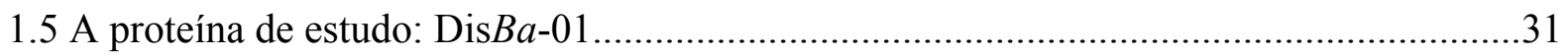

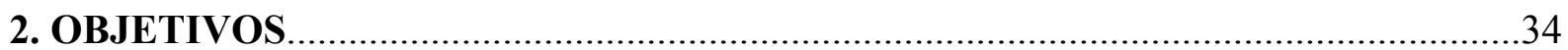

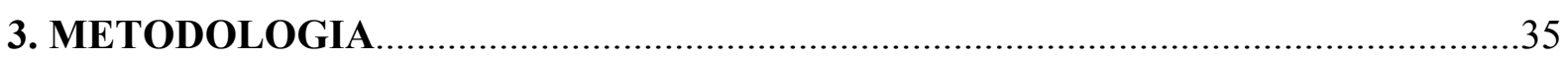

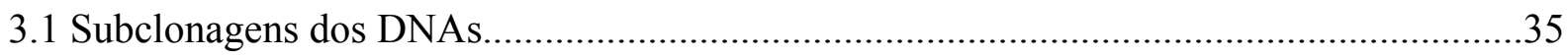

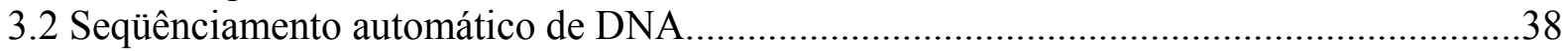

3.3 Expressão e Purificação das proteínas recombinantes......................................................38

3.4 Clivagem das proteínas de fusão e Purificação por gel filtração......................................39

3.5 Caracterização das proteínas recombinantes $\operatorname{DisBa}(\Delta 1-32)$ e $\operatorname{DisBa}(\Delta 1-36) \ldots \ldots \ldots \ldots \ldots \ldots . . . . . .40$

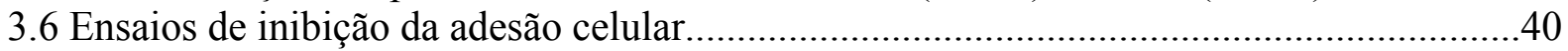

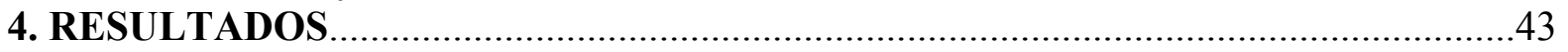

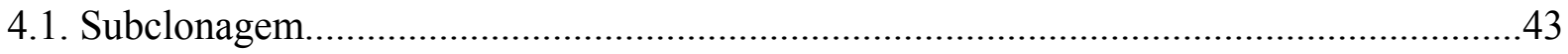

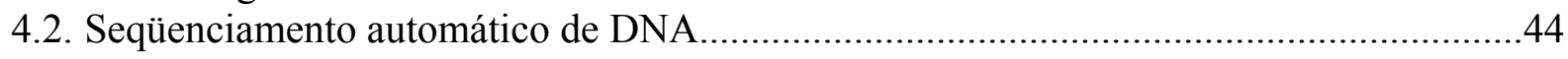

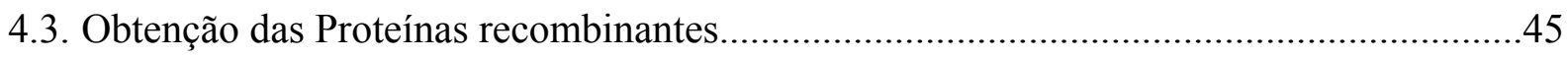

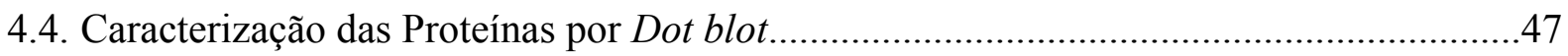

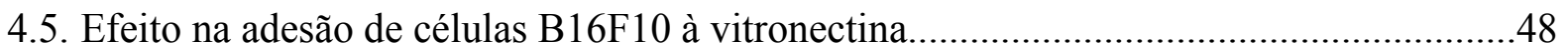

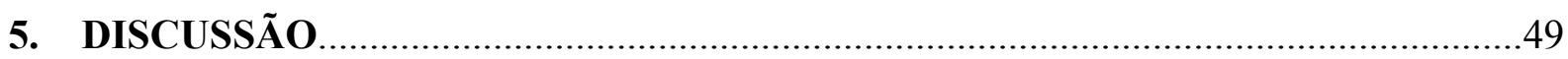

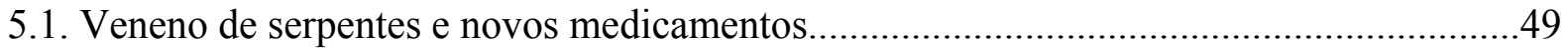

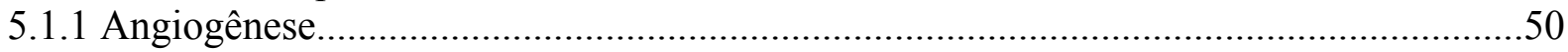

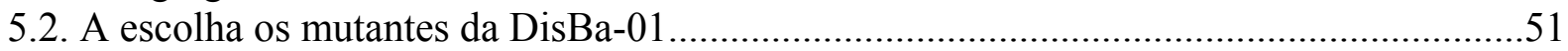

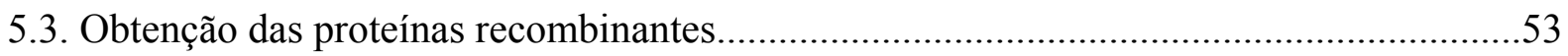

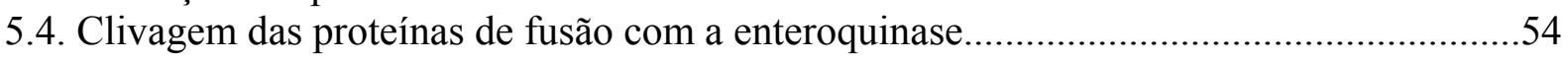

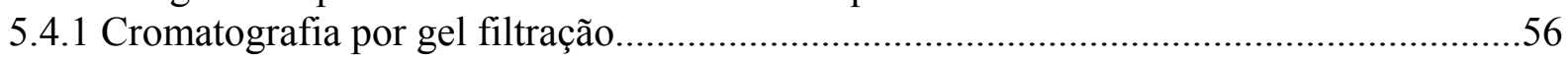

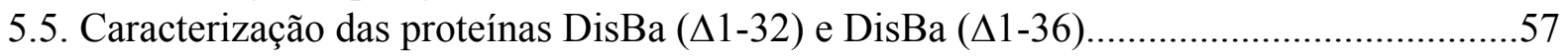

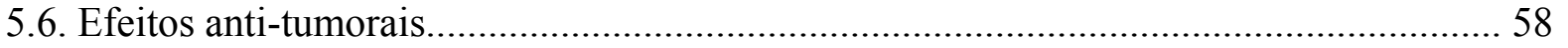

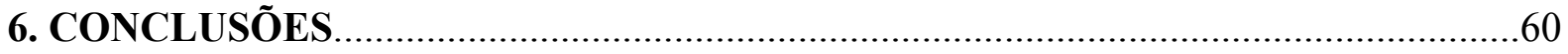

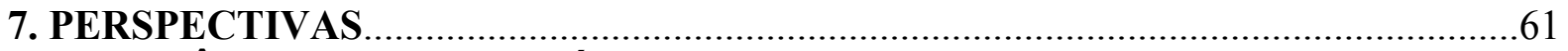

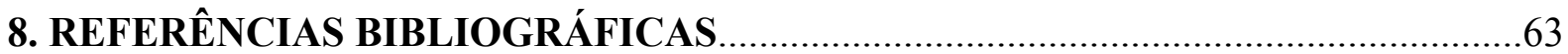




\section{1 - INTRODUÇÃO}

O Brasil possui uma grande biodiversidade, fornecendo uma valiosa oportunidade de exploração de moléculas bioativas para a descoberta e produção de novos fármacos. Venenos de serpentes possuem compostos que têm sido explorados como arsenais terapêuticos e um dos melhores exemplos da aplicação de substâncias derivadas de venenos é o Captopril, medicamento amplamente utilizado contra a hipertensão e cujo princípio ativo é derivado de um Inibidor da Enzima Conversora de Angiotensina, IECA, encontrado no veneno de Bothrops jararaca (BARREIRO; FRAGA, 2001). Entre as diversas classes de proteínas de venenos de serpentes que têm sido estudadas destacam-se as desintegrinas, que são moléculas cujos efeitos biológicos relacionam-se com suas ligações a receptores celulares e são potentes inibidores de agregação plaquetária e de adesão celular. Trabalhos recentes têm demonstrado resultados animadores na inibição do desenvolvimento de metástases e na prevenção da trombose, sugerindo a utilização dessas moléculas como uma alternativa terapêutica (BEVIGLIA; STEWART; NIEWIAROWSKI, 1995; DANEN et al., 1998; SHEU et al., 1995; SOUZA et al., 2000).

\section{1 - Bothrops alternatus}

As serpentes podem ser classificadas em dois grupos básicos: as peçonhentas, que conseguem inocular seu veneno no corpo da presa ou vítima, e as não peçonhentas, ambas encontradas no Brasil (MINISTÉRIO DA SAÚDE, s.d.). Existem três características fundamentais que distinguem as serpentes peçonhentas das não peçonhentas: a presença da fosseta loreal, o tipo de cauda e a presença de anéis coloridos. A fosseta loreal é um orifício termo-receptor, localizado entre o olho e a narina da serpente. O tipo de dentição é um 
aspecto que também pode distinguir as serpentes peçonhentas das não peçonhentas, mas sua verificação não é aconselhável pela necessidade de manipulação da serpente. No grupo das não peçonhentas, são observados dois tipos de dentição: a dentição áglifa (dentes fixos, pequenos e maciços) e dentição opistóglifa (além dos dentes fixos, pequenos e maciços, possuem um par de dentes mais longos com sulcos localizados no fundo da boca). No grupo das serpentes peçonhentas também existem dois tipos distintos: a dentição proteróglifa (um par de dentes dianteiro, fixo, pequeno e semi-canaliculado que injeta o veneno, semelhante aos demais dentes maciços) e dentição solenóglifa (os dentes fixos são menores e destacam-se os que injetam o veneno, que são longos, dianteiros, canaliculados e móveis), observada em jararacas e cascavéis (INSTITUTO BUTANTA, 2007).

Existem cerca de 3000 espécies de serpentes conhecidas, das quais mais de 400 espécies são consideradas venenosas. No Brasil, existem aproximadamente 250 espécies de serpentes, sendo que 70 são peçonhentas (PINHO; PEREIRA, 2001). Elas estão classificadas em cinco famílias maiores: Elapidae, Viperidae, Crotalidae, Hydrophidae e Colubridae (LU; CLEMERTSON, J.M.; CLEMERTSON, K.J., 2005). O envenenamento por serpentes da família Elapidae é altamente neurotóxico, enquanto os venenos da família Viperidae estão relacionados com os efeitos inflamatórios e hemorrágicos (JUNQUEIRA-DE-AZEVEDO et al., 2006).

O gênero Bothrops (jararacas) pertence à família Viperidae que possui fosseta loreal e cauda lisa até a extremidade. Neste gênero estão incluídas, aproximadamente, 30 espécies de serpentes encontradas em zonas rurais e periferias de grandes cidades, preferindo ambientes úmidos como matas e áreas cultivadas e locais onde tenha facilidade para proliferação de roedores (paióis, celeiros, depósitos de lenha). Estas serpentes são de grande importância médica para o Brasil, sendo o acidente botrópico responsável por cerca de $90 \%$ dos envenenamentos. A Bothrops alternatus, conhecida como urutu-cruzeiro, mede 
aproximadamente 1,5m de comprimento (Figura 1), e sua ocorrência é registrada no norte da Argentina, Uruguai, Paraguai e no sudeste e sul do Brasil (MISTÉRIO DA SAÚDE, s.d.).

O envenenamento do gênero Bothrops induz efeitos locais caracterizados por hemorragia, necrose, edema e dor intensa (SANCHEZ et al., 1992). De modo geral, o quadro clínico do envenenamento por serpentes é dependente de dois fatores: a toxicidade e a quantidade de veneno injetado. Há vários sintomas do envenemamento, como a paralisia flácida, coagulopatia e hemorragia, insuficiência renal, cardiotoxicidade e lesão local no tecido, que afetam o sistema nervoso central, o sistema cardiovascular, muscular e vascular (KOH; ARMUGAM; JEYASEELAN, 2006). A ocorrência do acidente ofídico está relacionada ao clima tropical e aumento da atividade humana nos trabalhos no campo. A faixa etária acometida varia de 15 a 49 anos. Quanto ao local da picada, o pé e a perna são os mais atingidos (PINHO; PEREIRA, 2001).

No Brasil, no ano de 2007, de acordo com dados do Instituto Butantan, foram registrados 28.321 casos de picadas de serpentes, sendo que apenas 111 resultaram em óbitos ( $0,39 \%$ do total). O gênero Bothrops é o responsável por cerca de $90 \%$ das notificações. No entanto, o único tratamento disponível consiste na administração do soro específico (MINISTÉRIO DA SAÚDE, 2001)

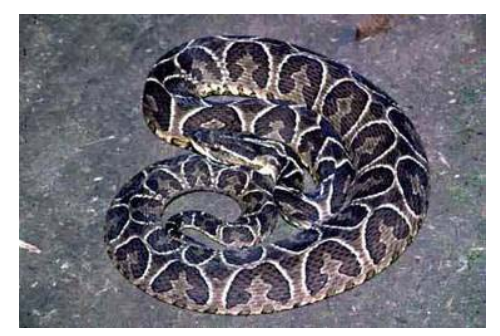

Figura 1: B. alternatus (urutu-cruzeiro) 


\section{2 - Metaloproteases}

Venenos de serpentes são misturas complexas de proteínas, nucleotídeos e íons inorgânicos. Peptídeos e polipeptideos compreendem $90 \%$ da massa seca do veneno e são responsáveis pela variedade de propriedades tóxicas. Classificam-se em várias famílias, como serino-proteases, metaloproteases, lectinas tipo-C, desintegrinas e fosfolipases $(\mathrm{KOH}$; ARMUGAM; JEYASEELAN, 2006; MARKLAND, 1998).

As metaloproteases de venenos de serpentes (SVMPs) compreendem uma família de endopeptidases dependente de $\mathrm{Zn}^{2+}$, que são responsáveis por efeitos hemorrágicos do envenenamento através da digestão de componentes da matriz extracelular, como o colágeno, a laminina e a fibronectina, sendo freqüentemente chamadas de hemorraginas (BARAMOVA et al., 1989; BJARNASON; FOX, 1994). As SVMPs são sintetizadas na forma de precursores inativos ou zimogênios, processados rapidamente na própria glândula venenífera para tornarem-se enzimas funcionais (BJARNASON; FOX, 1994; HITE et al., 1994; SHIMOKAWA et al., 1996). Baseado na estrutura dos domínios, essas proteínas foram divididas em quatro classes (HITE et al., 1994). A classe PI inclui as metaloproteases pequenas (20-30 kDa), com baixa ou nenhuma atividade hemorrágica, que possuem os domínios pró e metaloprotease. A classe PII inclui as toxinas de tamanho médio (30-60 kDa) e possui, além dos domínios pró e metaloprotease, um domínio desintegrina no C-terminal. As proteínas dessa classe liberam as desintegrinas RGD durante o processo proteolítico. A classe PIII é representada pelas grandes proteínas hemorrágicas $(60-100 \mathrm{kDa})$, que contêm um domínio "desintegrina-like" (XXCD ou SECD no lugar do RGD) e um domínio rico em cisteína. As proteínas da classe PIV possuem baixa atividade hemorrágica, mesmo contendo todos os domínios encontrados na classe PIII, com a adição de um domínio lectina-like tipo-C (BJARNASON; FOX, 1994; GRAMS et al., 1993; YAMADA; SHIN; MORITA, 1999). 
As SVMPs são membros da subfamília Reprolisina de metaloproteases assim como as ADAMs (Metalopeptidases e Desintegrinas de Mamíferos), que são semelhantes às proteínas da classe PIII de SVMPs na organização de seus domínios.

As ADAMs foram a primeira família de proteínas de membrana relatada com funções adesivas e anti-adesivas em seus domínios extracelulares (WOLFSBERG; WHITE, 1996). ADAMs são proteínas moduladoras expressas em mamíferos, que contêm um pró-domínio, um domínio metaloproteolítico, um domínio desintegrina, um domínio rico em cisteína, um domínio com repetições do fator de crescimento epitelial (EGF), uma região transmembrânica e uma região citoplasmática (Figura 2), relacionada com a transdução de sinais. Contudo, também podem se apresentar na forma solúvel pela remoção das regiões transmembrânica e citoplasmática (WOLFSBERG; WHITE, 1996).

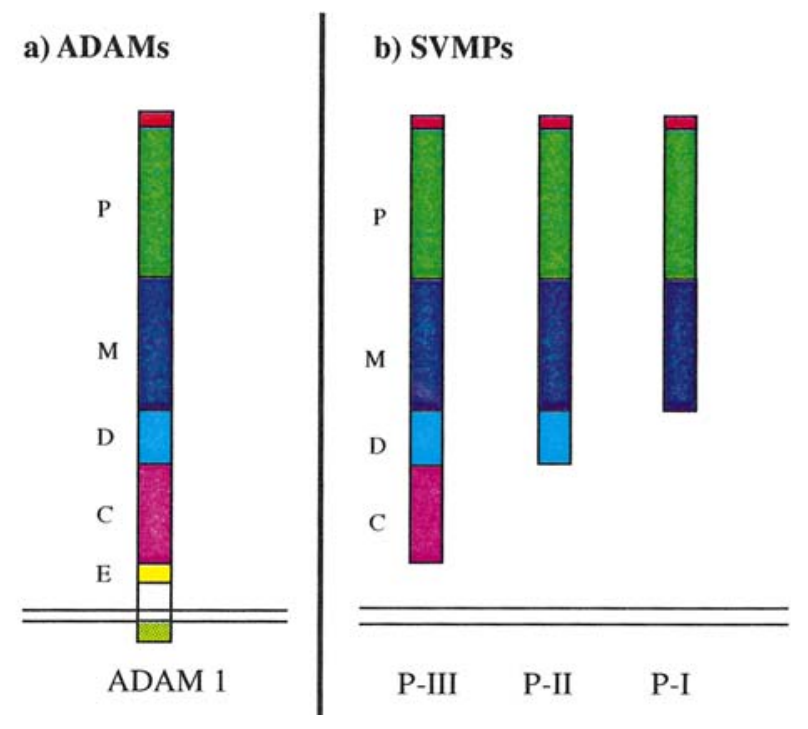

Figura 2: Organização dos domínios de ADAMs e SVMPs; (a) ADAMs: pro-domínio (P), metaloprotease-like (M), desintegrina-like (D), domínio rico em cisteína (C), EGF-like (E), domínio transmembrânico e citoplasmático ; (b) SVMPs: pro-domínio (P) e domínio metaloprotease (M); algumas contêm domínio desintegrina (D) ou domínio rico em cisteína (C) (WOLFSBERG; WHITE, 1996). 
Até o presente, aproximadamente 34 genes adam foram descritos em uma variedade de espécies, sendo encontrados 19 genes adam em humanos. As ADAMs 2, 7, 18, 20, 21, 29 e 30 são expressas predominantemente em testículos, ADAMs 8, 9, 10, 11, 12, 15, 17, 19, 22, 23, 28 e 30 apresentam uma ampla distribuição, sendo que as ADAMs 9, 12 e 19 foram originalmente encontradas em mioblastos (SEALS; COURTNEIDGE, 2008).

Estudos têm demonstrado um importante papel dessas moléculas no controle da fusão de membranas, liberação de citoquinas e fator de crescimento, migração celular, assim como processos de desenvolvimento muscular e fertilização através de ligações ADAM-integrina. Patologias como inflamação e câncer também envolvem membros da família das ADAMs (HUOVILA et. al, 2005; SEALS; COURTNEIDGE, 2008).

\section{3 - Integrinas e Desintegrinas}

A terminologia integrina descreve uma família de receptores da superfície celular que integram a matriz extracelular com o citoesqueleto intracelular, mediando a migração e adesão celular (HYNES, 1992; PLOW et al., 2000). Estes receptores são encontrados em muitas espécies animais, de esponjas a mamíferos, e estão envolvidos em processos celulares fundamentais, como crescimento e diferenciação celular, migração, sinalização, inflamação, trombose e metástase (GIANCOTTI; RUOSLAHTI, 1999; HUMPHRIES, 2000; HYNES; LANDER, 1992).

As interações integrina-ligante são determinadas por vários fatores, sendo que o principal fator da especificidade ao ligante deve-se à composição das subunidades de uma integrina. As integrinas são glicoproteínas heterodiméricas formadas por duas subunidades transmembrânicas $\alpha(120$ a 180 kDa) e $\beta(90$ a 110 kDa) associadas não-covalentemente (SHIMAOKA; JUNICHI; SPRINGER, 2002; WOLPERT, 2000). Em mamíferos, 18 tipos de 
subunidade $\alpha$ e 8 tipos de subunidade $\beta$ combinam-se em 24 receptores diferentes, divididos em dois grupos, um que contém e o outro sem um extra-domínio tipo A do fator de von Willebrand em suas subunidades $\alpha(\alpha \mathrm{A}$ ou $\alpha \mathrm{I})$. O domínio $\alpha \mathrm{A}$ é capaz de ligar-se a cátions bivalentes $\left(\mathrm{Ca}^{2+}\right.$ ou $\left.\mathrm{Mg}^{2+}\right)$ mediando a ligação com ligantes extracelulares, como as proteínas da matriz extracelular (fibrinogênio, vitronectina, laminina, fator de von Willebrand), VCAM, ICAMs e proteínas do plasma. A subunidade $\beta$ possui um domínio tipo-A, pouco conhecido, o domínio $\beta$ A. Em integrinas com os dois domínios A, o domínio $\alpha$ A é que participa da ligação com o ligante (MICHISHITA; VIDEM; ARNAOUT 1993; SEOW et al., 2002; XIONG et al., 2001). Cada heterodímero de integrina (Figura 3) possui de 3 a 8 sítios de ligação cátions divalentes, que promovem profundos efeitos na função da integrina. Coletivamente, eles podem atuar como efetores, promovendo a adesão a ligantes; como antagonistas, inibindo a adesão a ligantes; e como seletores, pela modificação da especificidade de adesão de ligantes à integrina (PLOW et al., 2000). A maior parte da molécula de integrina se encontra exposta no meio extracelular, enquanto que o citoesqueleto de actina e o maquinário de sinalização estão associados a um pequeno domínio citoplasmático (DZAMBA et al., 2001). 


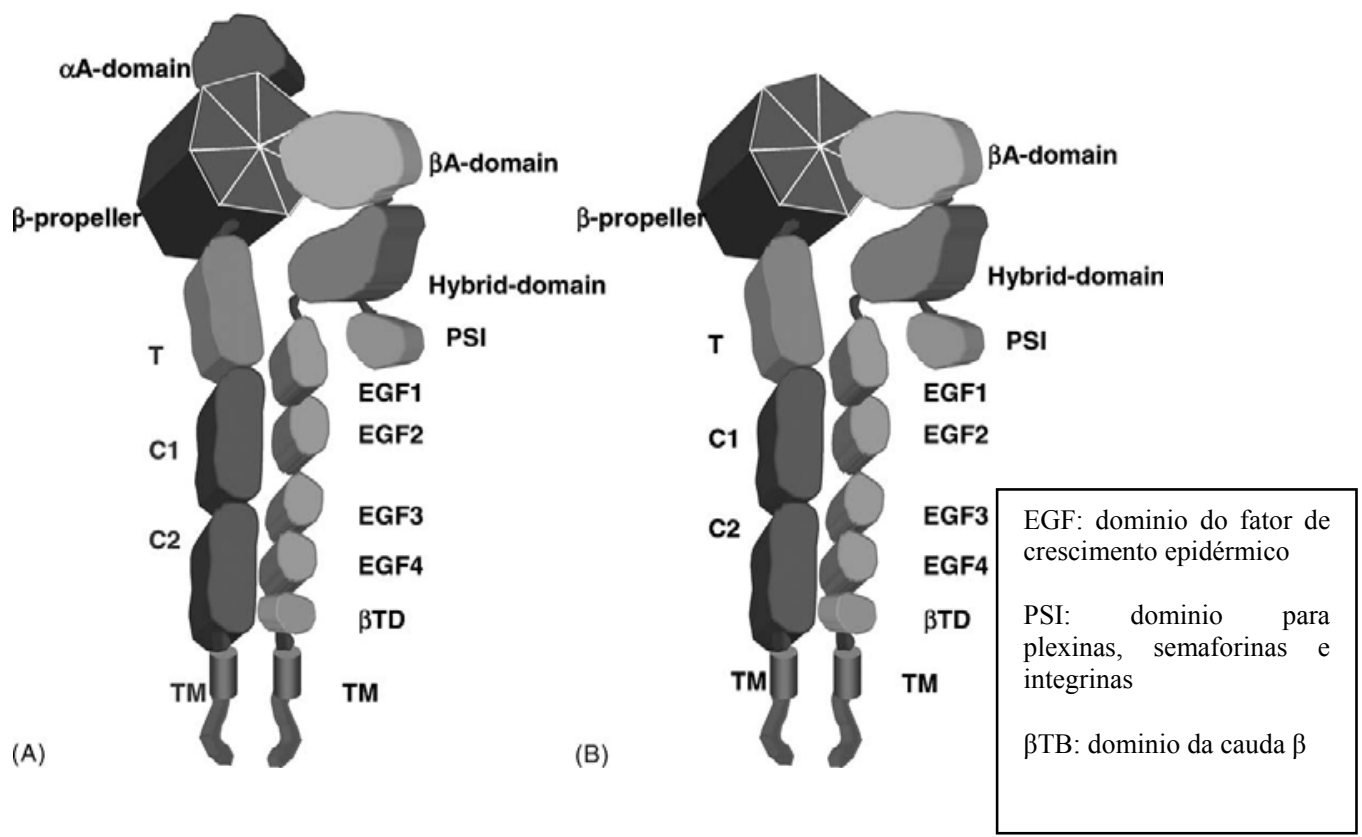

Figura 3: Representação esquemática da estrutura das subunidades $\alpha$ e $\beta$ de integrina. A subunidade $\alpha$ aparece em duas classes: uma contendo um domínio $\alpha \mathrm{A}$ na subunidade $\alpha$ (A) e outra sem o domínio $\alpha \mathrm{A}$ (B). Todas as subunidades $\beta$ aparecem com um domínio $\beta$ A. A região $\mathrm{N}$-terminal da subunidade $\alpha$ tem 7 seqüências repetitivas formadas em uma $\beta$-hélice, seguida por uma "coxa" (T) e duas "pernas"(C1, C2), uma hélice transmembrânica e um pequeno domínio citoplasmático. A porção Nterminal da subunidade $\beta$ tem um domínio PSI, que se liga através de pontes dissulfeto ao domínio EGF1, e um domínio IgG-like inserido no domínio $\beta$ A, para formar um domínio hibrido. Existem 4 domínios EGF-like (EGF 1-4) seguidos por uma hélice transmembrânica, e um pequeno domínio citoplasmático (SEOW et al., 2002).

Quase toda célula expressa uma ou várias integrinas. Aquelas integrinas contendo as subunidades $\alpha_{4}, \alpha_{5}, \alpha_{8}, \alpha_{\text {IIb }}$ ou $\alpha \mathrm{V}$ ligam-se a componentes da ECM que contém a seqüência RGD (Arg-Gly-Asp), denominadas fibronectina e vitronectina. Lamininas e colágenos também contêm a seqüência RGD, reconhecida pelas subunidades $\alpha_{3}, \alpha_{6}, \alpha_{7}$ (laminina) e $\alpha_{1}$, $\alpha_{2}, \alpha_{19}$ ou $\alpha_{11}$ (colágeno). Em geral, as integrinas de células hematopoiéticas ligam-se a receptores em outras células (VCAM e ICAMs) ou proteínas do plasma (fibrinogênio e fator de von Willebrand) e fatores complemento (iC3b) (VAN-DER-FLIER; SONNENBERG, 2001). 
Integrinas contendo as subunidades $\beta 1$ e $\beta 3$ estão principalmente envolvidas com interações célula-matriz extracelular (BILATO et al., 1997). A família das integrinas $\beta 3$ corresponde aos receptores $\alpha \operatorname{IIb} \beta 3$, encontrado em plaquetas e $\alpha \mathrm{V} \beta 3$, amplamente distribuído. A integrina $\alpha \operatorname{IIb} \beta 3$, possui maior afinidade pelo fibrinogênio e está envolvida nos mecanismos de hemostasia (XUE et al., 1997). A $\alpha \mathrm{V} \beta 3$ é um receptor importante na angiogênese, metástase, inflamação e remodelamento ósseo. Essa integrina se liga a múltiplos ligantes incluindo a vitronectina, angiostatina e osteopontina, além de servir como um receptor para diversos vírus como vírus da febre aftosa, adenovírus, e vírus da imunodeficiência humana (PLOW et al., 2000).

Se por um lado as integrinas são necessárias em uma série de processos fisiológicos, por outro, elas estão associadas a patologias como a neoplasia, metástase, disfunção imune, infecções virais, osteoporose e coagulopatia (ARNAOUT, 1990; HYNES, 1992).

As ligações reversíveis célula-matriz extracelular e célula-célula, mediada pela integrina, podem ser inibidas por pequenos peptídeos chamados desintegrinas. Estas moléculas contêm um domínio RGD que se liga às integrinas e impede a ligação, mediada por integrinas, das células com as proteínas da matriz extracelular (WOLPERT, 2000; SÁNCHEZ et al., 2006). As desintegrinas pertencem a uma família de proteínas de baixo peso molecular ricas em cisteína, obtidas através do processo proteolítico das proteínas da classe PII e PIII de veneno de serpentes (GOULD et al., 1990; NIEWIAROWSKI et al., 1994; YAMADA; SHIN; MORITA, 1999). Elas foram identificadas, primeiramente, como inibidores da agregação plaquetária, por agirem como antagonista do receptor de fibrinogênio para a glicoproteína IIb/IIIa ( $\alpha$ IIb $\beta 3$ ) de membrana de plaquetas (HUANG et al., 1987; GOULD et al., 1990). O isolamento e caracterização de desintegrinas que não inibem agregação plaquetária (isto é, desintegrinas diméricas que não contém o motivo RGD) foram possíveis com o desenvolvimento, a partir dos anos 1990, de ensaios usando linhagens de células que 
expressam integrinas específicas (MARCINKIEWICZ et al., 1999a, MARCINKIEWICZ et al., 1999b).

Atualmente, a família das desintegrinas pode ser convenientemente dividida em cinco diferentes grupos de acordo com o comprimento e o número de pontes dissulfeto dos peptídeos (Figura 4). O primeiro grupo inclui desintegrinas pequenas compostas de 41-51 resíduos de aminoácidos e 4 pontes dissulfeto. O segundo grupo é formado pelas desintegrinas de tamanho médio que contém aproximadamente 70 resíduos de aminoácidos e 6 pontes dissulfeto. $\mathrm{O}$ terceiro grupo inclui desintegrinas longas com aproximadamente 84 resíduos interligados por 7 pontes dissulfeto. A quarta subfamília de desintegrinas inclui o grupo das tipo-desintegrinas (disintegrin-like) derivadas das PIII Metaloproteinases de Venenos de Serpentes (SVMPs). Desintegrinas PIII são proteínas modulares contendo um domínio N-terminal de aproximadamente 100 resíduos e 8 pontes dissulfeto e um domínio Cterminal rico em cisteínas de aproximadamente 100 resíduos e 6 pontes de dissulfeto (CALVETE et al., 2000a). O quinto grupo é composto de moléculas de desintegrinas homo e hetrerodiméricas, que contém desintegrinas de aproximadamente 67 resíduos com 10 cisteínas envolvidas na formação pontes dissulfeto intra-e inter-cadeias (CALVETE et al., 2000b; BILGRAMI et al., 2004). 

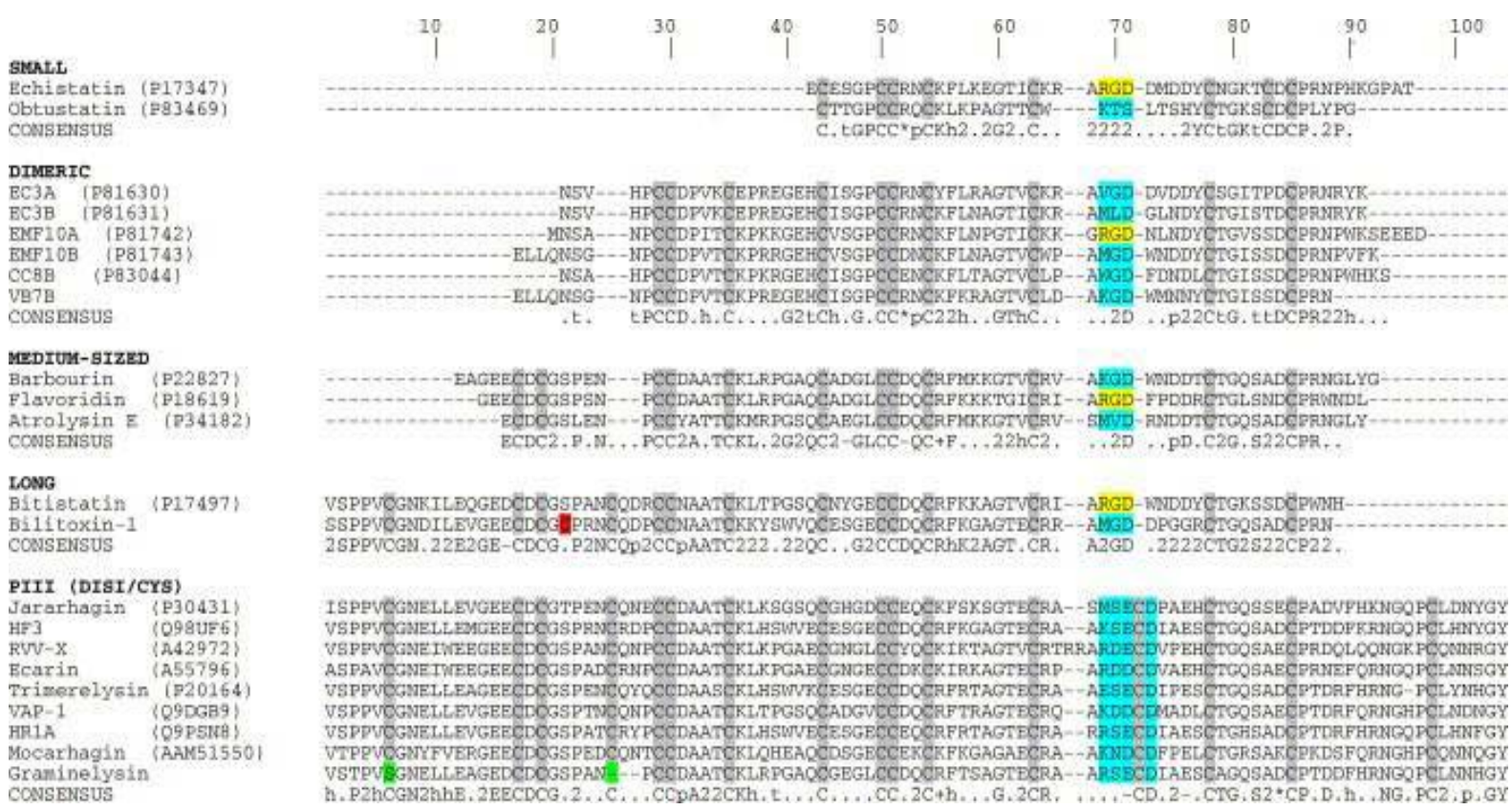

VSPPVCGNKILDQGEDCDCGSPANCOCDRCONAATCKKLTPGSOCNYGECCDOCEFKKAGTVCERI--ARGD-WNDDYCTGKSSDCPWYH2SPPVOGM. 22B2GE-CDCG.P2MCOD2CCPAATC222.220C.,G2CCDQCRhK2AGT.CR. A2GD .2222CTG2S22CP22.

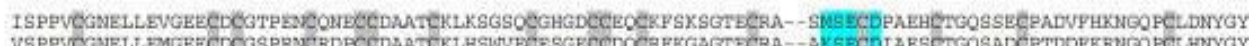

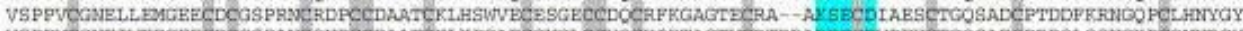

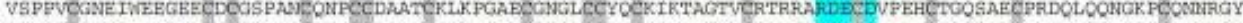

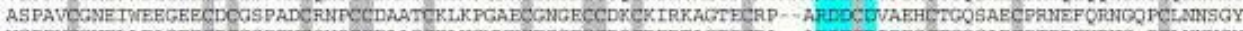

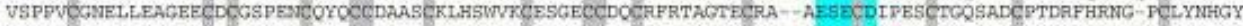

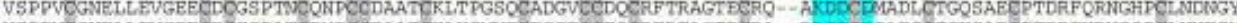

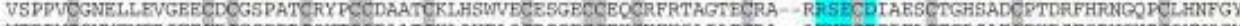

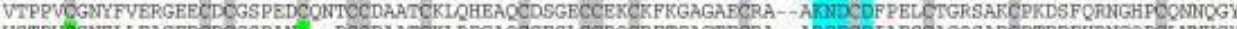

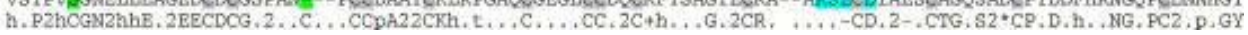

Figura 4: Análise de múltiplas seqüências de polipeptídeos selecionados de diferentes subfamílias de desintegrinas (CALVETE et al., 2005). Os resíduos de cisteínas estão mostrados em fundo cinza. As posições de cisteínas conservadas estão mostradas em verde. A cisteínas mostrada em vermelho encontra-se na molécula da desintegrina bilitoxin, uma molécula homodimérica. O motivo RGD é mostrado em amarelo.

As desintegrinas podem ser divididas, funcionalmente, em três grupos de acordo com sua seletividade para integrina e a presença de motivos específicos. O primeiro grupo inclui a maioria das desintegrinas monoméricas que contém o domínio RGD. O segundo grupo é representado pelo domínio MLD, contendo desintegrinas que interagem com integrinas de leucócitos. O terceiro grupo foi recentemente descoberto e consiste em desintegrinas contendo o domínio KTS, inibindo a integrina $\alpha 1 \beta 1$ receptora especifica para o colágeno. A busca por inibidores de integrinas dependentes do domínio RGD têm sido alvo da pesquisa farmacológica. Em distúrbios tromboembólicos, o objetivo principal é bloquear a ligação do fibrinogênio à integrina $\alpha \operatorname{IIb} \beta 3$ em plaquetas. As desintegrinas RGD também podem bloquear a ação da integrina $\alpha \mathrm{V} \beta 3$ em células tumorais, impedindo sua adesão à matriz extracelular, 
reduzindo sua mobilidade e inibindo a metástase (KOH; ARMUGAM; JEYASEELAN, 2006; MARCINKIEWICZ, 2005).

Desintegrinas monoméricas foram primeiramente descritas como potentes inibidores da ligação do fibrinogênio à integrina $\alpha \operatorname{IIb} \beta 3$ de plaquetas. Desintegrinas diméricas foram descobertas posteriormente. Estudos indicam que desintegrinas diméricas são amplamente distribuídas em venenos de Echis e Vipera, e provavelmente também nos venenos de outras espécies de Crotalidae e Viperidae, que são fontes ricas de desintegrinas monoméricas (HUANG, et al., 1987; MCLANE et al., 1998).

Devido a essas funções, as desintegrinas de venenos de serpentes são importantes para estudos básicos de reconhecimento celular em malignidade e trombose, bem como potencial terapêutico (BEVIGLIA; STEWART; NIEWIAROWSKI, 1995; CHIANG; YANG; HUANG, 1995; SHEU; HUANG, 1994; SHEU et al., 1995).

\subsection{1- Aspectos estruturais-funcionais de Desintegrinas}

A Ressonância Magnética Nuclear (RMN) tem sido a técnica mais utilizada para determinar a estrutura de diversas desintegrinas, embora mais recentemente a estrutura cristalográfica de algumas desintegrinas tenha sido relatada na literatura. Estudos de RMN de pequenas (echistatin, 2ECH, 1RO3) e médias (kistrin, 1KST; flavoridin, 1FVL; salmosin, 1IQ2) desintegrinas e estudos cristalográficos de uma desintegrina de tamanho médio (trimestatin, 1J2L) demonstraram que a seqüência RGD está localizada no ápice de um loop móvel, saliente 14-17 $\AA$ da proteína (ADLER et al., 1991; COOKE et al., 1991; SMITH et al., 1996) (Figura 5). Este loop, responsável pela ligação à integrinas, apresenta em comum

em todas as subfamílias das desintegrinas (Figura 4) a presença de um resíduo ácido (aspártico em desintegrinas pequenas, diméricas, médias e longas; glutâmico ou aspártico em 
desintegrinas com domínios tipo-desintegrina/rico em cisteínas). A estrutura cristalográfica do segmento extracelular da integrina $\alpha \mathrm{V} \beta 3$ complexada com um ligante RGD (XIONG et al., 2002) mostrou que o peptídeo se encaixa na fenda formada entre os domínios $\alpha \mathrm{V}$ e $\beta 3$. A cadeia lateral da Arg da desintegrina é mantida por interações com carboxilas 218 e 150 da integrina, o resíduo Gly faz várias interações hidrofóbicas com o domínio $\alpha \mathrm{V}$ e o Asp interage principalmente com resíduos do domínio $\beta$ A. Assim, foi proposto que o resíduo conservado Asp talvez seja responsável pela ligação de desintegrinas à integrinas que compartilham uma subunidade $\beta$, enquanto os dois outros resíduos do motivo de ligação à integrinas ( $R G, M G$, WG, ML, VG) podem ditar a especificidade primária de integrina (CALVETE et al., 2005).

A

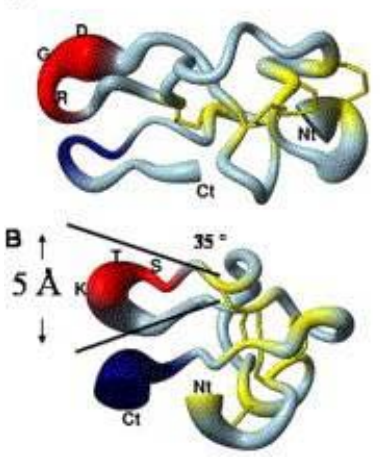

c

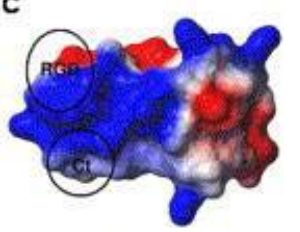

D

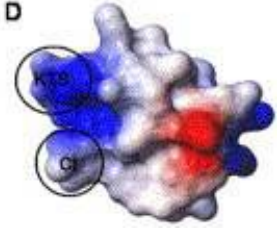

Figura 5: Estruturas de desintegrinas pequenas, determinadas por RMN (Calvete et al., 2005): Aestrutura da echistatin (desintegrina-RGD; código PDB 1RO3); B- estrutura da obtustin (desintegrina KTS; código PDB 1MPZ). As pontes dissulfeto e o tripeptídeo estão mostrados em amarelo e vermelho, respectivamente. A região C-terminal está colorida em azul escuro. C e D, potencial de superfície eletrostática das moléculas echistatin e obtustin, respectivamente: cargas negativas estão mostradas em vermelho e positivas em azul. Os motivos de reconhecimento (RGD e KTS) são mostrados em círculos. 
A trimestatin (código PDB 1J2L) foi a primeira desintegrina de veneno de serpente a ter sua estrutura cristalina resolvida. A estrutura da trimestatin, em 1,7 Å de resolução, revela um núcleo rígido formado por um número de voltas e loops estabilizado por seis pontes dissulfeto. Densidades eletrônicas da seqüência RGD são claramente visíveis na ponta de um loop hairpin, de forma que os resíduos de aminoácidos Asp e Arg de cadeias laterais apontam em direções opostas (FUJII et al., 2003).

A molécula de schistatin isolada do veneno de Echis carinatus, foi a primeira desintegrina homodimérica a ter a estrutura cristalina resolvida ( $2.5 \AA$ de resolução). Sua estrutura é bem ordenada, com quatro pontes dissulfeto intramolecular. Os dois monômeros estão fortemente ligados através de duas pontes dissulfeto intermoleculares na região Nterminal. As duas cadeias diméricas divergem nas suas regiões C-terminal, expondo o motivo Arg-Gly-Asp em direções opostas, aumentando a sua eficiência na ligação às integrinas. Seqüência e características estruturais dos monômeros de schistatin sugerem que eles têm a capacidade de forte ligação com ambas integrinas $\alpha \operatorname{IIb} \beta 3$ e $\alpha \mathrm{V} \beta 3$. O homodímero liga-se a integrinas, aparentemente, com uma maior afinidade do que os monômeros e também desempenha um papel importante na sinalização da via (BILGRAMI et al., 2004).

A busca de melhor entendimento para o reconhecimento e especificidade das desintegrinas levou a estudos envolvendo peptídeos menores, sintéticos ou nativos. Diversos estudos têm sido descritos na literatura, com peptídeos contendo mutações tanto na região do motivo RGD como fora dessa região. Estudos com peptídeos sintéticos cíclicos também têm sido relatados.

Um dos primeiros estudos de mutagênese sítio-dirigida descreve a obtenção de peptídeos mutantes da kistrina, uma desintegrina de veneno de Agkistrodon rhodostoma constituída por 68 resíduos de aminoácidos que inibe o receptor de fibrinogênio GPIIb/IIIa, apresentando portanto, atividade inibitória de agregação plaquetária. (DENNIS et al., 1990). 
Um dos trabalhos pioneiros mostram 43 peptídeos derivados de kistrina e suas atividades para GPIIb/IIIa (DENNIS et al., 1993). A substituição de alaninas nos resíduos R49, G50 e D51, do motivo RGD, levou a formação de moléculas com atividades de inibição da agregação plaquetária de 90, 2 e 200 vezes mais fracas, respectivamente, que a molécula de kistrina. Esses resultados mostraram a importância dos resíduos do motivo RGD na atividade da kistrina. A natureza crítica do resíduo aspartato do motivo RGD para a alta afinidade de ligação foi demostrada pelo mutante conservativo D51E que apresentou uma baixa atividade de inibição de agregação plaquetária (100 vezes menos) (DENNIS et al., 1993).

A idéia de que a composição dos resíduos que flanqueiam o motivo RGD é um fator importante para a atividade das desintegrinas tem sido verificada e comprovada por diversos estudos. Um desses estudos descreve os peptídeos sintéticos derivados da salmosina e saxatilina, desintegrinas que ligam se fortemente à $\alpha \mathrm{V} \beta 3$, uma das integrinas que contribuem para a angiogênise de tumores, angiogênise de retina e osteoporose (KIM et al., 2005). Esses peptídeos RGD que se ligam de forma específica à integrinas $\alpha \mathrm{V} \beta 3$ são potentes compostos de partida para desenvolvimento de medicamentos contra câncer. Estudos comparativos mostraram que peptídeos RGD-cíclicos são quase 30 vezes mais ativos do que peptídeos lineares, em ensaios de ligação com integrinas e de agregação plaquetária. Estes dados apóiam a hipótese de que RGDs cíclicos são mais estáveis e eficientes do que peptídeos lineares, reforçando a importância da conformação das desintegrinas, que é fornecida principalmente pelas pontes dissulfeto (KIM et al., 2005).

A echistatina, um peptídeo de 49 resíduos de aminoácidos isolado do veneno de Echis sochureki carinatus (GAN et al., 1998), é uma das desintegrinas mais estudadas e caracterizadas. Resíduos adjacentes, na região $\mathrm{C}$-terminal, ao motivo $\mathrm{R}^{24} \mathrm{GD}^{26}$ contribuem para a inibição seletiva das integrinas $\alpha \operatorname{IIb} \beta 3, \alpha \mathrm{V} \beta 3$ e $\alpha 5 \beta 1$ pela echistatina (WIERZBICKA- 
PATYNOWSKI et al., 1999). Foi mostrado que o triptofano na posição 27 favorece o reconhecimento da integrina $\alpha \operatorname{IIb} \beta 3$ e que o ácido aspártico parece ser crucial para inibir as integrinas $\alpha \mathrm{V} \beta 3$ e $\alpha 5 \beta 1$. Além disso, a substituição da $\mathrm{Met}^{28}$ por asparagina aboliu completamente a habilidade da echistatina em bloquear cada uma dessas integrinas, enquanto que a substituição da $\mathrm{Met}^{28}$ por leucina diminuiu seletivamente a atividade inibitória da echistatina somente para a ligação com a integrina $\alpha 5 \beta 1$. Outros estudos com echistatina já haviam mostrado a importância funcional da região C-terminal da molécula em modular a afinidade de ligação da desintegrina com a integrina $\alpha$ IIbß3 (WRIGHT et al., 1993). Foi demonstrado que um peptídeo sintético da região C-terminal da echistatina inibiu a ligação da echistatina à integrina $\alpha \operatorname{IIb} \beta 3$, ativou a ligação da integrina à ligantes imobilizados e aumentou a ligação de fibrinogênio à plaquetas tratadas com o peptídeo (sendo portanto, um peptídeo com menor poder de inbição da ligação dos ligantes à integrina).

O número elevado de estudos com desintegrinas (nativas e sintéticas) tem contribuído para o esclarecimento de diversos aspectos da ligação desintegrina-integrina. Neste contexto, estudos estruturais podem contribuir de forma especialmente importante, principalmente aqueles que envolvam a estrutura do complexo desintegrina-integrina. No entanto, devido às dificuldades em cristalizar o complexo, uma molécula bastante grande, até o momento (Fevereiro de 2008) somente uma estrutura tem sido reportada na literatura. Os autores XIONG et al. (2002) determinaram a estrutura do segmento extracelular da integrina $\alpha \mathrm{V} \beta 3$ em complexo com um peptídeo cíclico apresentando o motivo RGD (Figura 5). A estrutura mostra que o peptídeo se liga na interface entre as subunidades $\alpha \mathrm{V}$ e $\beta 3$ (em azul e vermelho na Figura 6), respectivamente, e faz contatos com ambas as sub-unidades. Importantes mudanças conformacionais, tanto terciárias como quaternárias, foram observadas em decorrência da presença do ligante. Embora XIONG et al. (2002) tenha mostrado de forma inequivocada as interações no complexo estudado, os próprios cientistas reconhecem que os 
resultados obtidos representam uma visão minimalista das reais mudanças conformacionais que devem ocorrer durante a interação de integrinas com a desintegrinas, uma vez que estas são geralmente moléculas maiores e mais complexas do que o peptídeo estudado.

Embora os estudos, bioquímicos e estruturais, com peptídeos derivados de desintegrinas sejam de grande importância para determinação dos resíduos de aminoácidos envolvidos no reconhecimento e especificidade das proteínas, tem sido reportado que os peptídeos nativos são inibidores aproximadamente 1000 vezes mais potentes do que peptídeos RGD lineares. Esse comportamento é atribuído à conformação favorável do motivo RGD nas moléculas nativas (e maiores) que é dependente de aminoácidos mais afastados do motivo RGD (LU et al., 1996). Portanto, o estudo de minimização das moléculas de desintegrinas é importante para o esclarecimento de quais regiões das moléculas de desintegrinas são fundamentais para sua atividade e é a proposta do presente trabalho.

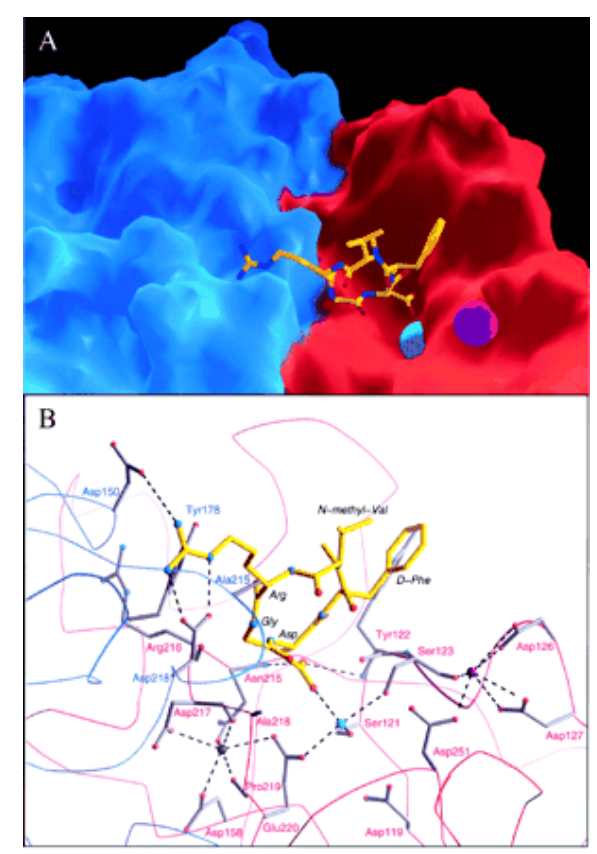

Figura 6: Estrutura tridimensional do segmento extracelular da integrina $\alpha \mathrm{V} \beta 3$ em complexo com um peptídeo cíclico apresentando o motivo RGD (XIONG et al., 2002). (A) Representação da superfície do sítio de ligação, com o peptídeo mostrado como modelo de bolas e bastões. Em azul, o segmento da sub-unidade $\alpha \mathrm{V}$ e em vermelho segmento da sub-unidade $\beta 3$. (B) Interações entre integrina e ligante. 


\section{4- Desenvolvimento de novos fármacos derivados de moléculas de desintegrinas}

Enquanto os componentes originais de veneno de serpente são geralmente inadequados como terapêuticos, intervenções pela química medicinal e pesquisa farmacêutica tem possibilitado o uso das proteínas de veneno de serpente como terapêuticos. Exemplos de medicamentos provenientes de proteínas de venenos de serpentes que tiveram progresso clínico são apresentados na Tabela 1 (KOH; ARMUGAM; JEYASEELAN, 2006).

Captopril, sintetizado em 1977, foi o primeiro fármaco derivado de veneno de serpente a chegar ao mercado farmacêutico e atua como um potente inibidor da Enzima Conversora de Angiotensina (ECA), usado no tratamento da hipertensão.

Tabela 1- Medicamentos/Diagnóstico clínico dos venenos de serpentes (KOH; ARMUGAM; JEYASEELAN, 2006)

\begin{tabular}{lll}
\hline Medicamento/nome comercial ${ }^{\circledR}$ & \multicolumn{1}{c}{ Alvo e funções/ tratamento } & \multicolumn{1}{c}{ Fonte } \\
\hline Integrilin (eptifibatide) & inibidor da ACE /pressão alta & Bothrops jaracusa (Brasil) \\
Aggrastat (tirofiban) & $\begin{array}{l}\text { inibição da agregação plaquetária/ } \\
\text { Síndrome coronária aguda }\end{array}$ & Sisturus miliarus barbouri \\
Ancrod (Viprinex) & $\begin{array}{l}\text { Miocárdio, isquemia } \\
\text { Defibrase }\end{array}$ & Echis carinatus (África) \\
inibidor de fibrinogênio/AVC & Agkistrodon rhodostoma \\
Hemocoagulase & $\begin{array}{l}\text { inibidor de trombina e protrombina/ } \\
\text { Infarto cerebral agudo, inespecíficas } \\
\text { efeitos de trombina-like e atividade de } \\
\text { tromboplastina/tratamento e prevenção } \\
\text { de hemorragias }\end{array}$ & Bothrops moojeni \\
Protac/protein C activator & $\begin{array}{l}\text { ativador da proteína C/diagnóstico clínico atrox } \\
\text { da desordem hemostática }\end{array}$ & A. contortix contortix \\
Reptilase & $\begin{array}{l}\text { Diagnóstico de transtorno de coagulação } \\
\text { sangǘnea }\end{array}$ & Bothrops jaraca (América \\
do Sul) \\
ativador de protrombina/diagnóstico \\
Exanta; ximelagatran
\end{tabular}


As moléculas de desintegrina, por interagirem especificamente com determinadas classes de integrinas, apresentam um grande potencial para desenvolvimento de fármacos para doenças importantes e severas como tromboembolia e câncer. Dois exemplos de medicamentos derivados de moléculas de desintgrinas pertencem a classe dos antagonistas dos receptores da glicoproteína GPIIb/IIIa são o Intergrilin e o Aggrastat. Esta classe de medicamentos bloqueia a via final comum da agregação plaquetária, independentemente do estímulo inicial. A ativação dos receptores existentes na superfície das plaquetas (ao redor de 80.000 para cada plaqueta), denominados de glicoproteína (GP) IIb/IIIa, constitui-se no mecanismo final e obrigatório de agregação plaquetária, em conseqüência de alteração morfológica sofrida pelo receptor, que aumenta a sua afinidade para ligar-se à molécula de fibrinogênio, elemento que funciona como ponte de ligação entre duas plaquetas (NICOLAU, 2007). A molécula eptifibatide, um heptapeptídeo ciclizado e constituído por seis aminoácidos e um resíduo mercaptopropionil (Figura 7a) é um derivado de uma desintegrina de veneno de Sistrurus miliarus barbouri e o princípio ativo do medicamento comercializado com o nome de Integrilin ${ }^{\circledR}$, (Millennium Pharmaceuticals). O tirofiban é um derivado sintético, não-peptídeo, de molécula pequena, que possui em sua estrutura molecular uma seqüência derivada de RGD (arginina-glicina-aspartato) (Figura 7b). O medicamento que tem o tirofiban como principio ativo é o Aggrastat comercializado pela Merck Co. Inc. 


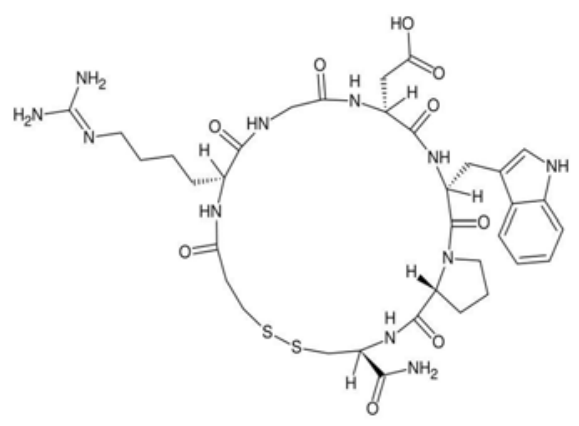

(A)

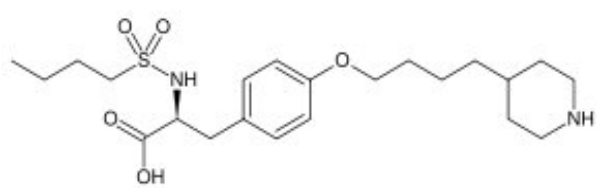

(B)

Figura 7: Moléculas da classe dos antagonistas dos receptores da glicoproteína GPIIb/IIIa: (A) eptifibatide e (B) tirofiban (NICOLAU, 2007).

Medicamentos contra o câncer, derivados de desintegrinas, também estão sendo desenvolvidos. O pentapeptídeo cíclico RGD cilengitide também conhecido como EMD121974, é um inibidor das integrinas $\alpha \mathrm{V} \beta 3$ e aV $\beta 5$ e está sendo estudado como medicamento antiangiogênico e anticancerígeno (STUPP et al., 2007). Essas integrinas estão envolvidas na formação de novos vasos, um processo essencial no crescimento de câncer. Em câncer de próstata, especificamente, já é conhecido que as integrinas estão envolvidas na metástase com expressão diferencial em células tumorais. Os tumores e células endoteliais vasculares produzem fatores, tais como fator de crescimento endotelial vascular e fator de crescimento básico de fibroblastos, que promovem a neovascularização, que tem sido associada à progressão do câncer de próstata (MACDONALD et al., 2008). Os estudos já estão na fase II com pacientes com câncer de próstata (BEEKMAN et al., 2006), que é a fase onde são avaliados a segurança e eficiência do provável medicamento. A cilengitide está também sendo avaliada na fase I, em crianças com câncer no cérebro (MACDONALD et al., 2008). 


\section{5.- A proteína de estudo DisBa-01}

A DisBa-01 (AAO75107) é uma desintegrina RGD recombinante de massa molecular aparente de aproximadamente $12 \mathrm{kDa}$, que foi isolada de uma biblioteca de cDNA construída a partir de RNAs de veneno de B. alternatus (RAMOS, 2005). A seqüência da proteína, obtida a partir da seqüência de DNA, é mostrada na Figura 8. A Dis $B a-01$ é composta por 78 resíduos de aminoácidos conectados através de 6 pontes dissulfeto, o que a classifica na subfamília das desintegrinas médias (CAlVETE et al., 2003).

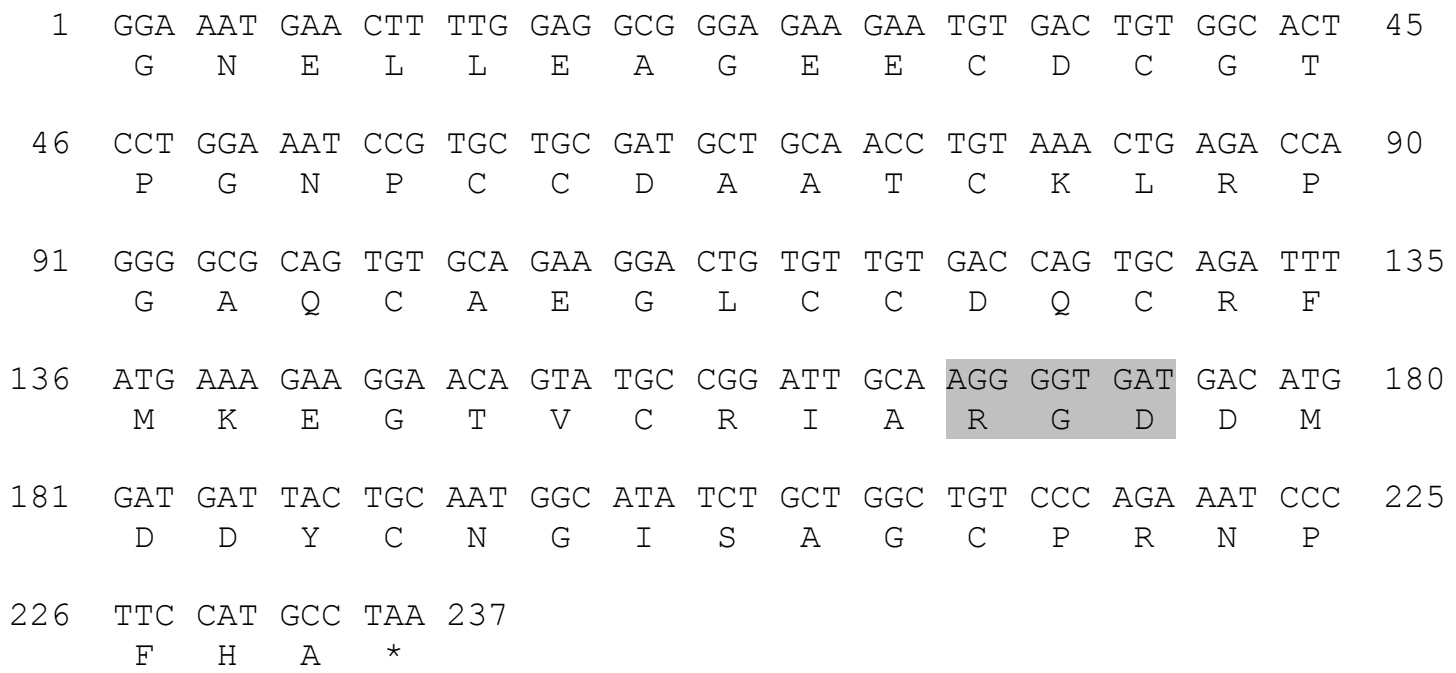

Figura 8: Seqüência de nucleotídeos e aminoácidos pDisBa-01. O motivo RGD e os códons correspondentes são representados em fundo cinza. O códon de parada é representado por um (*).

A Dis $B a-01$, proteína recentemente estudada, possui alta afinidade pelas integrinas $\alpha \mathrm{V} \beta 3$ e $\alpha_{\mathrm{IIb}} \beta_{3}$, que são proteínas envolvidas na formação de tumores e trombose, respectivamente (RAMOS, 2005). Estudos do efeito da DisBa-01 na adesão de células B16F10 à vitronectina mostraram forte inibição da ligação dessas células à vitronectina na 
presença da Dis $B a-01\left(\mathrm{IC}_{50}=225 \mathrm{nM}\right)$. Também foram feitos experimentos que constataram, na presença da DisBa-01, forte inibição da agregação plaquetária induzida por colágeno $\left(\mathrm{IC}_{50}=235 \mathrm{nM}\right)$ e por ADP $\left(\mathrm{IC}_{50}=124 \mathrm{nM}\right)$ em plasma rico em plaquetas de coelho. Estudos in vivo também mostraram que a DisBa-01 é capaz de inibir a formação de focos metastáticos e de trombos (RAMOS, 2008).

O modelo molecular tridimensional da Dis $B a-01$ em complexo com o segmento extracelular da integrina $\alpha \mathrm{V} \beta 3$ (Figura 9) prediz uma grande superfície de contato com a subunidade $\beta 3$, sendo que a região $\mathrm{N}$-terminal da proteína DisBa-01 não participa da interação entre a desintegrina e a integrina (RAMOS, 2008). A ausência de interação da porção N-terminal da DisBa-01 na ligação desta com a integrina, possibilita o desenvolvimento de ligantes estruturalmente reduzidos, que mantenham as atividades encontradas na molécula Dis $B a-01$. O estudo de mutantes estruturais da Dis $B a-01$ pode contribuir para o melhor entendimento das porções moleculares responsáveis pela interação com integrinas, fornecendo valiosas informações para a elaboração do desenho de um possível fármaco contra doenças como o câncer e a trombose.

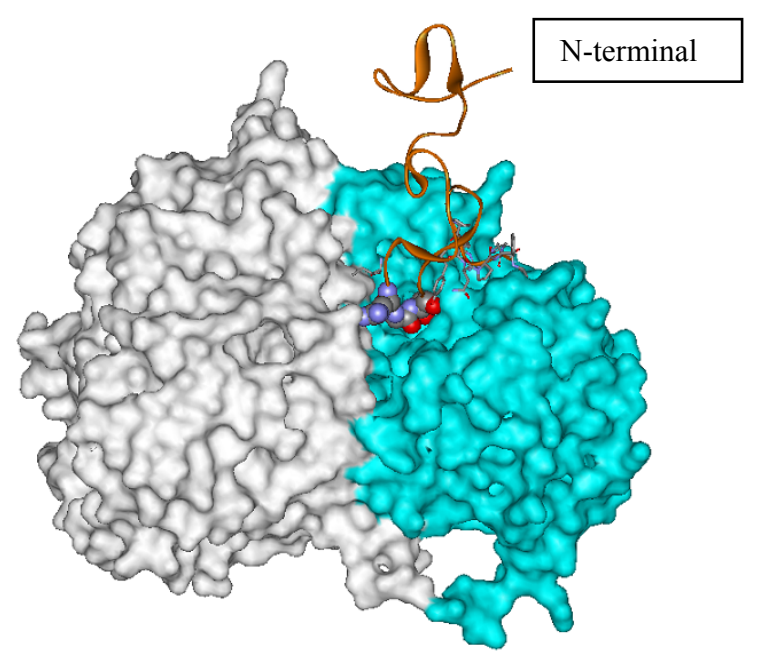

Figura 9: Modelo do complexo $\alpha \mathrm{V} \beta 3$-Dis $B a-01$ : aspecto da interação geométrica entre a DisBa-01(vermelho) e a subunidade $\alpha$ do receptor (branco) e subunidade $\beta$ (azul) (RAMOS, 2005). 
Devido a essa característica, a Dis $B a-01$ mostra-se uma proteína promissora como ponto de partida na busca de moléculas mutantes minimizadas, que possam manter suas funções biológicas. A proposta do presente trabalho é o estudo de mutantes da molécula de Dis $B a-01$, modificadas na porção N-terminal, que provavelmente não está envolvida na sua atividade. 


\section{2.- OBJETIVOS}

Diante do potencial efeito inibidor de agregação plaquetária e de adesão celular promovido pela desintegrina Dis $B a-01$, e da predição de que a região $\mathrm{N}$-terminal da proteína não interage com a integrina $\alpha \mathrm{V} \beta 3$, o presente trabalho teve como objetivos principais o estudo de minimização da DisBa-01 e análise das funções biológicas das moléculas minimizadas.

Para atingir esses objetivos foram estabelecidas as seguintes etapas:

2.1- Desenhos de oligonucleotídeos para amplificação dos DNAs correspondentes às duas diferentes moléculas minimizadas da DisBa-01;

2.2- Subclonagem dos DNAs e expressão das duas moléculas reduzidas em sistemas heterólogos;

2.3- Purificação das proteínas recombinantes;

2.4- Caracterização bioquímica das proteínas recombinantes;

2.5- Ensaios de inibição da adesão celular in vitro das proteínas recombinantes. 


\section{3 - METODOLOGIA}

\section{1 - Subclonagens dos DNAs}

Baseando-se na análise do seqüenciamento da DisBa-01 (Figura 8), foram desenhados oligonucleotídeos com inclusão dos sítios de clivagem para as enzimas de restrição BamHI e EcoRI para subclonagem unidirecional, a fim de construir duas formas minimizadas da molécula de Dis $B a-01$. Uma das moléculas tem os 32 primeiros aminoácidos eliminados, isto é, inicia no resíduo 33 correspondente á Dis $B a-01$, e foi denominada Dis $B a(\Delta 1-32)$, e outra que inicia no resíduo 37, denominada $\operatorname{Dis} B a(\Delta 1-36)$.

\section{Primers utilizados (Bioneer):}

$\operatorname{Dis} B a(\Delta 1-32)$ :

Reverse: CGC GAA TTC TTA GGC ATG GAA GGG ATT (sítio para EcoRI)

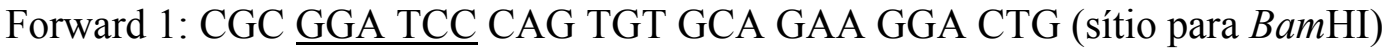

$\operatorname{Dis} B a(\Delta 1-36)$ :

Reverse: CGC GAA TTC TTA GGC ATG GAA GGG ATT (sítio para EcoRI)

Forward 2: CGC GGA TTC GGA CTG TGT TGT GAC CAG (sítio para BamHI)

(ATT: códon de parada)

As amplificaçôes dos DNAs foram feitas por reações de PCR, utilizando como molécula molde o plasmídeo pET28a-Dis $B a-01$, gentilmente cedido pela Profa. Dra. Heloisa S. Selistre-de-Araújo, do Departamento de Ciências Fisiológicas da UFSCar. Foram utilizados nas reações os oligonucleotídeos sintetizados $(10 \mu \mathrm{M})$, dNTPs $(10 \mathrm{mM})$, a enzima taq DNA polimerase (Biotools) e seu respectivo tampão contendo $\mathrm{MgCl}_{2}$ (Biotools), em um volume de reação final de $50 \mu \mathrm{L}$. Foram testadas as seguintes temperaturas de anelamento: 
55, 62 e $65{ }^{\circ}$ C. Esta temperatura varia com a temperatura de melting (Tm) dos oligonucleotídeos.

O termociclador (Mastercycler Gradient Eppendorf) foi configurado para o seguinte programa (Figura 10):

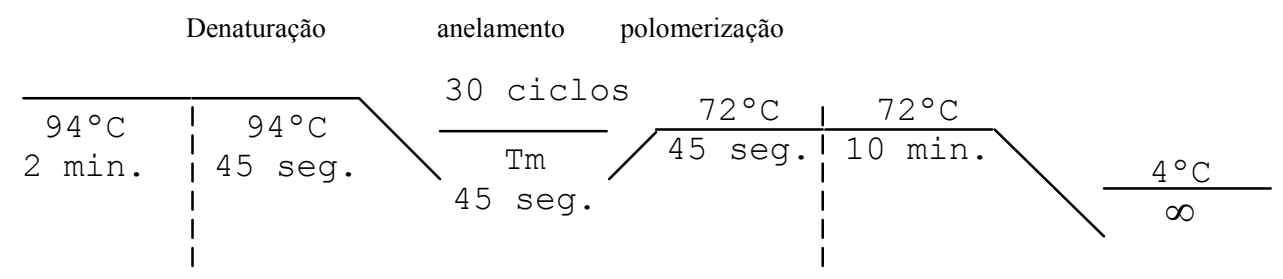

Figura 10: Programa utilizado nas reações de PCR para obtenção dos DNAs DisBa ( $\Delta 1$ 32) e DisBa ( $(1-36)$.

Os DNAs amplificados foram digeridos com as enzimas de restrição BamHI e EcoRI e ligados ao vetor pET 32a, previamente digerido com as mesmas enzimas. O vetor pET 32a (Novagen) permite a expressão da proteína alvo em fusão com o C-terminal de uma seqüência codificadora de 109 amioácidos da proteína tiorredoxina (Trx.Tag ${ }^{\mathrm{TM}}$ ) em fase com His-tag, sítio para trombina, S-tag, sítio para enteroquinase e uma His-tag opcional no C-terminal, o que facilita a purificação em cromatografia de afinidade. A Figura 11 mostra o mapa do vetor pET32a (+), da Novagen.

As moléculas de DNA foram ligadas, na proporção molar de 1:4 de vetor e inserto, utilizando a enzima T4 DNA ligase (Promega) a $16^{\circ} \mathrm{C}$ por 19 horas. O produto de cada uma das duas ligações foi utilizado para transformação da linhagem DH5 $\alpha$ de E. coli para propagação do vetor. O processo de transformação foi analisado por PCR de colônias e análise de restrição dos plasmídeos, através de eletroforese em gel de agarose (1\%) 
empregando-se brometo de etídio $(0,5 \mu \mathrm{g} / \mathrm{mL})$ em tampão TAE $1 X$ (40 mM Tris-acetato, 1mM EDTA pH8.0).
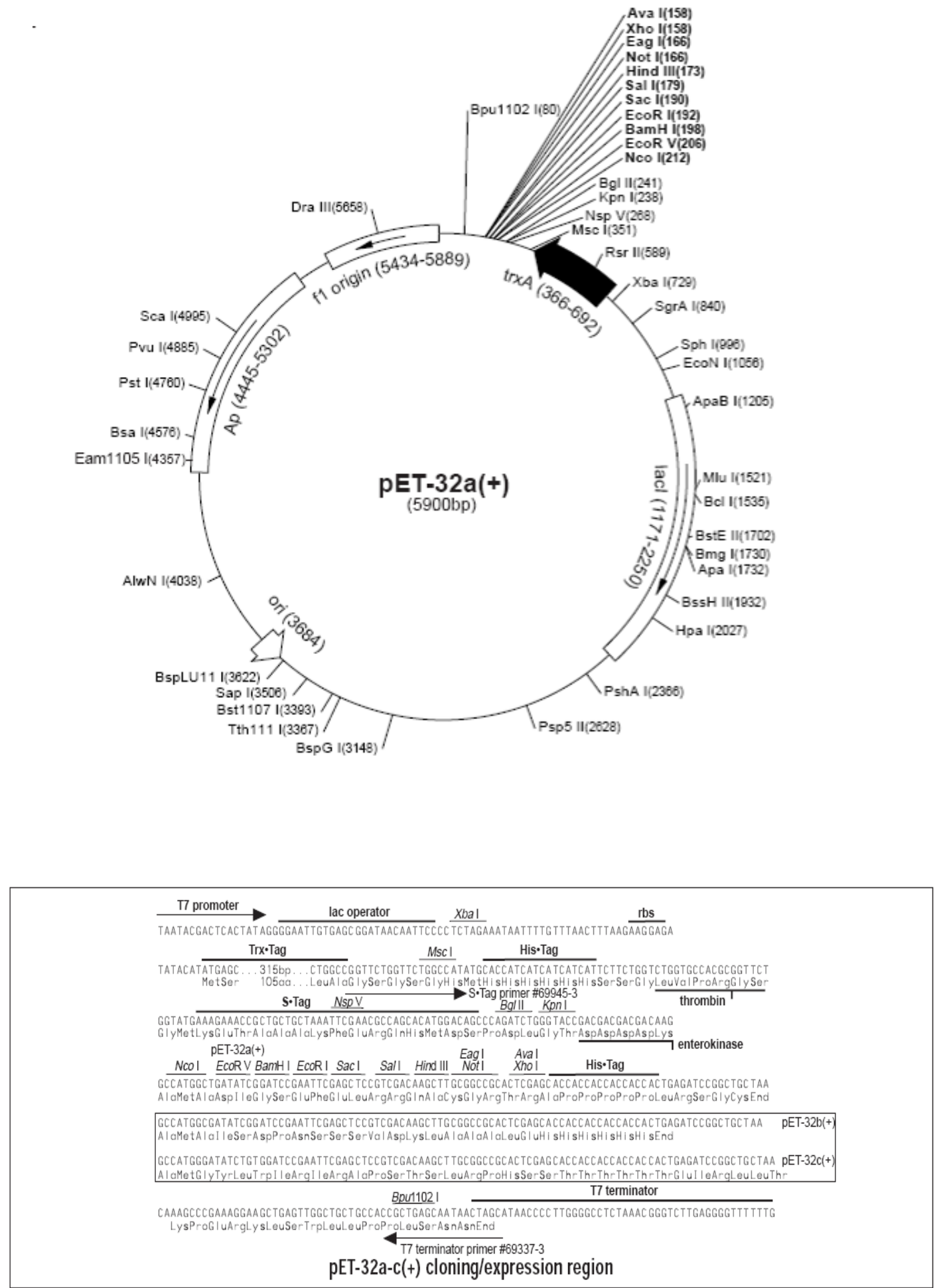

Figura 11: Mapa do vetor pET 32a (+), da Novagen. 


\section{2- Seqüênciamento automático de DNA}

As subclonagens foram validadas através do seqüênciamento de DNA, utilizando um seqüenciador automático (ABI Prism 377TNA Sequencer) sob a supervisão do Prof. Dr. Otávio Thiemann do IFSC-USP.

Os oligonucleotídeos iniciadores utilizados nas reações de PCR foram F1 e Reverse para $\mathrm{pDis} B a(\Delta 1-32)$ e $\mathrm{F} 2$ e Reverse para $\mathrm{pDis} B a(\Delta 1-36)$. As concentrações dos oligonucleotídeos foram ajustadas para 5 pmoles/ $\mu 1$ e a dos vetores para $50 \mathrm{ng} / \mu 1$.

\section{3- Expressão e Purificação das proteínas recombinantes}

A linhagem BL21(DE3) de E.coli foi utilizada para a expressão das proteínas $\mathrm{pDis} B a(\Delta 1-32)$ e $\mathrm{pDis} B a(\Delta 1-36)$ em fusão com a tiorredoxina. Os pré-inóculos foram preparados contendo $5 \mathrm{ml}$ de meio LB acrescido de ampicilina $(30 \mu \mathrm{g} / \mathrm{mL})$ e o gérmen de bactéria BL21(DE3) de E.coli. As culturas de bactérias foram incubada a $37{ }^{\circ} \mathrm{C}$ por 16 horas sob agitação de $250 \mathrm{rpm}$.

Os inóculos para produção das proteínas mutantes foram preparados a partir de $1 \%$ do pré-inóculo, em $250 \mathrm{~mL}$ de meio LB na presença da ampicilina. As culturas permaneceram sob agitação a $37^{\circ} \mathrm{C}$ até atingir uma densidade ótica (DO) a $600 \mathrm{~nm}$ de aproximadamente 0,6 , quando a expressão das proteínas foi induzida pela adição de $0,3 \mathrm{mM}$ de IPTG. Após a indução por 4 horas a $37^{\circ} \mathrm{C}$, as culturas foram centrifugadas a $9000 \mathrm{rpm}$ durante 20 min a $4^{\circ} \mathrm{C}$, sendo o sobrenadante descartado e as células do pellet ressupendidas em $12 \mathrm{~mL}$ de tampão usado em coluna de Níquel (110 mM de Tris, $300 \mathrm{mM}$ de $\mathrm{NaCl}$ e 10\% de glicerol pH 8,0).

A lise das células foi obtida com 8 minutos de sonicação (Sonic Desmembrator Fisher Scientific mode 500), sendo 10 segundos de pulso e 10 segundos de repouso. Posteriormente, 
as amostras foram centrifugadas a $8000 \mathrm{rpm}$ por 10 minutos a $10^{\circ} \mathrm{C}$, para obtenção das proteínas de interesse na fração solúvel.

As amostras do sobrenadante (pré-coluna) foram purificadas em $1 \mathrm{~mL}$ de resina de níquel (Qiagen) por afinidade, previamente equilibrada com $5 \mathrm{~mL}$ de tampão da coluna, descrito anteriormente. Foram coletados $10 \mathrm{~mL}$ de void e $10 \mathrm{~mL}$ de eluído na lavagem da coluna. As proteínas Dis $B a(\Delta 1-32)$-Trx e Dis $B a(\Delta 1-36)-\operatorname{Trx}$ foram eluídas em $2 \mathrm{~mL}$ de tampão da coluna de níquel acrescido de $150 \mathrm{mM}$ de imidazol.

Para o acompanhamento dessas etapas, foram utilizados géis SDS 15\%.

\section{4- Clivagem das proteínas de fusão e Purificação por gel filtração}

As proteínas de fusão $\operatorname{Dis} B a(\Delta 1-32)$-Trx e Dis $B a(\Delta 1-36)$-Trx, purificadas em resina de Níquel, foram dialisadas contra tampão EKMax $\left(50 \mathrm{mM}\right.$ de Tris e $10 \mathrm{mM}$ de $\mathrm{CaCl}_{2} \mathrm{pH}$ 8,0), para retirada do sódio, utilizando uma membrana de diálise com corte de 6-8 kDa (Spectrum Laboratories Inc), sendo posteriormente clivadas com a enzima Enteroquinase Max (Invitrogen). Previamente, as amostras de proteínas de fusão foram quantificadas utilizando-se um espectrofotômetro a $280 \mathrm{~nm}$, baseando-se na análise da curva de BSA. As amostras dialisadas apresentaram um rendimento de $0,5 \mathrm{mg} / \mathrm{mL}$. Com base nesses dados, foram realizados testes de clivagem com a enzima Enteroquinase Max nas concentrações 0,2 U e $0,5 \mathrm{U}$, sendo coletadas alíquotas após 1,4 e 18 horas de reação a $4^{\circ} \mathrm{C}$.

As soluções de proteínas clivadas com enteroquinase foram concentradas em speedvac (SpeedVac ${ }^{\circledR}$ Plus - Thermo Savant) até atingir o volume de $1 \mathrm{~mL}$ e purificadas por gel filtração em coluna Superdex 75 (GE Healthcare-Hiload ${ }^{\mathrm{TM}}$ 16/60) acoplada a um AKTA (Amersham Biosciences). A coluna foi previamente equilibrada com $120 \mathrm{~mL}$ de tampão (50 $\mathrm{mM}$ de Tris e $160 \mathrm{mM}$ de $\mathrm{NaCl} \mathrm{pH}$ 8,0). Foram coletadas frações de $1 \mathrm{~mL}$ em um fluxo de 
0,5 $\mathrm{mL} / \mathrm{min}$. As frações eluídas da coluna foram concentradas em speedvac até o volume de $1 \mathrm{~mL}$. Essas amostras foram analisadas através de eletroforese em géis de tricina.

\section{5- Caracterização das proteínas recombinantes $\operatorname{Dis} B a(\Delta 1-32)$ e $\operatorname{Dis} B a(\Delta 1-36)$}

O Dot blot é uma técnica usada para detectar biomoléculas, que consiste na imobilização do DNA ou da proteína em suporte adequado para imobilização (freqüentemente membrana) e posterior detecção por sondas ou anticorpos, respectivamente.

Foram aplicados $10 \mu \mathrm{L}$ de solução das proteínas $\operatorname{Dis} B a(\Delta 1-32)$ e $\operatorname{Dis} B a(\Delta 1-36)$ na concentraçâo de $10 \mu \mathrm{M}$ e, como controle positivo, $5 \mu \mathrm{L}$ da Dis $B a-01$, na concentração de $100 \mu \mathrm{M}$, diretamente sobre a membrana de nitrocelulose (BioAgency). Após secagem, a membrana foi lavada com TBS $1 \mathrm{X}$ e incubada por $1 \mathrm{~h}$ com o $1^{\circ}$ anticorpo (anti-Dis-Ba01 diluição 1: 64000). A membrana foi então retirada da solução que continha o $1^{\circ}$ anticorpo e lavada com TBS $1 \mathrm{X}$ e incubada por $1 \mathrm{~h}$ com o $2^{\mathrm{o}}$ anticorpo (anti-IgG de coelho 1:10000). Após reação, a membrana foi colocada em uma solução reveladora (SIGMA FAST $^{\mathrm{TM}}$ BCIP/NBT tablet) por 5 minutos e depois foi descorada com água mili-Q.

\section{6 - Ensaios de inibição da adesão celular}

Os experimentos de adesão celular foram realizados em colaboração com a Profa. Dra. Heloisa S. Selistre-de-Araújo, do Departamento de Ciências Fisiológicas da Universidade Federal de São Carlos. As amostras de proteínas puras $\operatorname{Dis} B a(\Delta 1-32)$ e $\operatorname{Dis} B a(\Delta 1-36)$ foram dialisadas contra tampão PBS (Phosphate Buffer Saline), e suas concentrações foram medidas com o kit de ensaio de proteína BCA (Perbio). A concentração de proteínas utilizadas nos ensaios foi de $1 \mu \mathrm{M}$. 
A vitronectina (Invitrogen), proteína adesiva envolvida na adesão de células como ligante da integrina $\alpha \mathrm{V} \beta 3$, foi imobilizada em uma placa de 96 poços $(1 \mu \mathrm{g} /$ poço $)$ a $4^{\circ} \mathrm{C}$ durante a noite. Após o tempo de incubação, os poços foram bloqueados com $200 \mu 1$ de solução de BSA 1\% em tampão de adesão (Hepes), por 2 horas a temperatura ambiente.

As células de melanoma de camundongo B16F10 foram utilizadas para os ensaios de adesão por expressarem altos níveis de integrina $\alpha \mathrm{V} \beta 3$. As células foram cultivadas em garrafas contendo meio RPMI 1640 (soro fetal bovino 10\%, glutamina, penicilina, estreptomicina e geneticina). Após cultivo, as células foram lavadas com PBS 1X e centrifugadas a $1500 \mathrm{rpm}$ por 5 minutos a temperatura ambiente. Estas células foram desaderidas das garrafas pela tripsina, cuja ação foi neutralizada pela adição de meio RPMI 1640, e centrifugadas a $1500 \mathrm{rpm}$ por 5 minutos. O pellet obtido foi ressuspendido em $10 \mathrm{~mL}$ de tampão de adesão (HEPES 20mM, $\mathrm{NaCl} 150 \mathrm{mM}, \mathrm{MgSO}_{4}$ 5mM, KCL 5mM, MnCl 1mM, pH 7,35) Após contagem das células com uma câmara de Neubauer, estas foram marcadas com 12,5 $\mu \mathrm{M}$ de 5-chloromethylfluorescein diacetate (CMFDA), agindo por 30 minutos a 37 ${ }^{\circ} \mathrm{C}$. Depois de retirado o excesso de solução marcadora, as soluções do poço foram preparadas. As proteínas $\operatorname{Dis} B a(\Delta 1-32)$, Dis $B a(\Delta 1-36)$ e Dis $B a-01$ foram colocadas em tampão de adesão e, posteriormente, foram acrescentadas às células, sendo esta solução mantida a $37^{\circ} \mathrm{C}$ por 30 minutos. Em seguida, foi feito o plaqueamento, aguardando o tempo de 30 minutos para as células aderirem. As células não aderidas foram removidas pela lavagem dos poços com tampão de adesão por três vezes.

As células foram lisadas com uma solução de Triton X-100 0,5\% adicionada a cada poço $(100 \mu \mathrm{L})$, por 20 minutos a temperatura ambiente e protegidas da luz. O registro da fluorescência da placa foi realizado em um fluorímetro (Spectra Max Gemini XS) com comprimento de onda de $485 \mathrm{~nm}$ de excitação e $538 \mathrm{~nm}$ de emissão. Para a análise estatística dos ensaios de inibição da adesão celular, os experimentos foram realizados em triplicata 
(ensaios independentes), sendo utilizada para o controle positivo a proteína Dis $B a-01$ e para o controle negativo a BSA $1 \%$ em tampão de adesão. $\mathrm{O}$ valor de $\mathrm{IC}_{50}$ foi calculado e comparado com o obtido para a molécula de DisBa-01. 


\section{RESULTADOS}

\section{1- Subclonagem}

Foram construídas duas moléculas menores da Dis $B a-01$, Dis $B a(\Delta 1-32)$ e Dis $B a(\Delta 1$ 36) que se referem a moléculas com menos 32 e 36 aminoácidos na região N-teminal, respectivamente.

A amplificação dos DNAs foi feita por reação de PCR usando como molde o plasmídeo pET28a-DisBa-01, gentilmente cedido pela Profa. Dra. Heloisa S. Selistre-deAraújo, do Departamento de Ciências Fisiológicas da UFSCar. Os genes amplificados apresentaram maior rendimento na temperatura de melting a $65^{\circ} \mathrm{C}$. Estes genes foram clonados no vetor pET32a, que permite a expressão da proteína de interesse em fusão com a tiorredoxina e o peptídeo de 6 histidinas.

As clonagens analisadas através de PCR de colônia (Figura 12) e análise de restrição (Figura 13) em gel de agarose $1 \%$, demonstraram um tamanho de banda esperado para $\mathrm{pDis} B a(\Delta 1-32)$ e $\mathrm{pDis} B a(\Delta 1-36)$, entre as bandas de $200 \mathrm{pb}$ e de $100 \mathrm{pb}$, correspondendo a 141 pb e $129 \mathrm{pb}$, respectivamente.

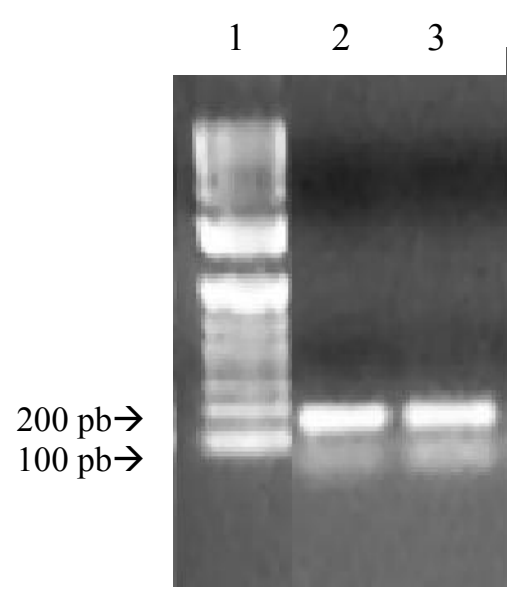

Figura 12: Análise por PCR de colônia dos transformantes com os DNAs pDis $B a(\Delta 1-$ 32) e pDis $B a(\Delta 1-36)$ em gel de agarose $1 \%$ 1) ladder $1 \mathrm{~Kb}$ plus; 2) amplificação $\mathrm{pDis} B a(\Delta 1-32) ; 3)$ amplificação $\operatorname{pDisBa}(\Delta 1$ 36).

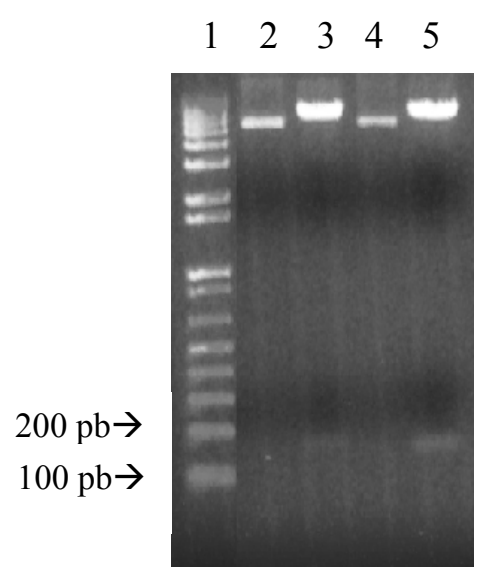

Figura 13: Análise de restrição dos plasmídeos pDis $B a(\Delta 1-32)$ e pDis $B a(\Delta 1-36)$ em gel de agarose $1 \%$ - 1) ladder $1 \mathrm{~Kb}$ plus; 2$) \mathrm{pDis} B a(\Delta 1$ 32); 3) pDis $B a(\Delta 1-32)$ clivado com Eco $R I$ e BamHI; 4) pDisBa ( $\Delta 1-36)$; 5) pDisBa $(\Delta 1-36)$ clivado Eco RI e BamHI. 


\section{2- Seqüenciamento automático de DNA}

No seqüenciamento dos DNAs usou-se como molde os plasmídeos $\mathrm{pDis} B a(\Delta 1-32)$ e $\mathrm{pDis} B a(\Delta 1-36)$ e seus respectivos oligonucleotídeos iniciadores F1-reverse e F2-reverse, confirmando que os genes estão com suas seqüências esperadas em fase de leitura correta (Figuras 14 e 15).

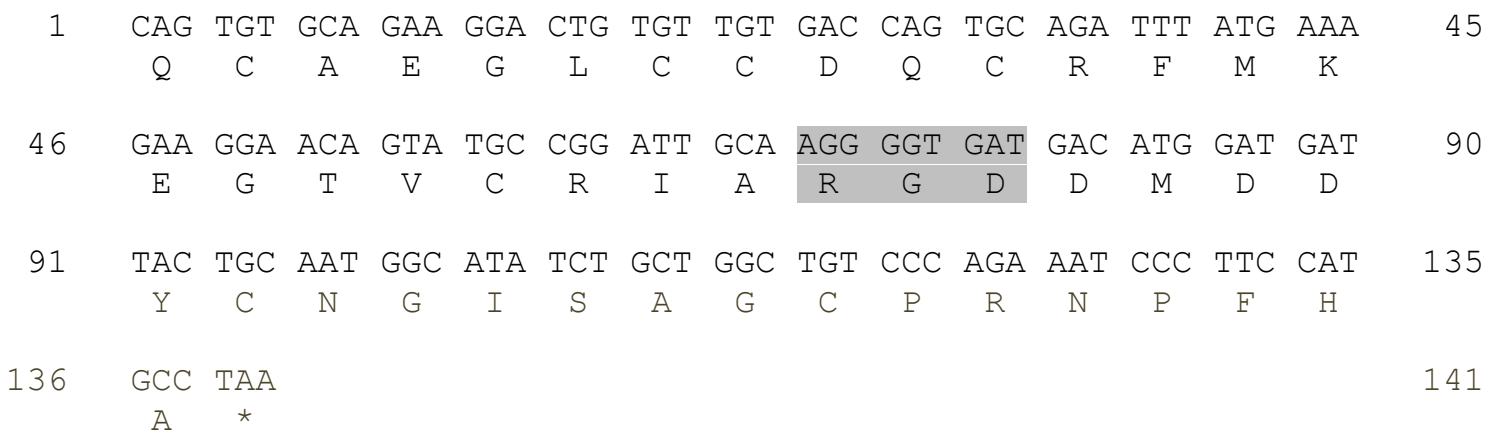

Figura 14: Seqüência de nucleotídeos e aminoácidos deduzido a partir do pDis $B a(\Delta 1-32)$. O motivo RGD e os códons correspondentes são representados em fundo cinza. O códon de parada é representado por um $(*)$.

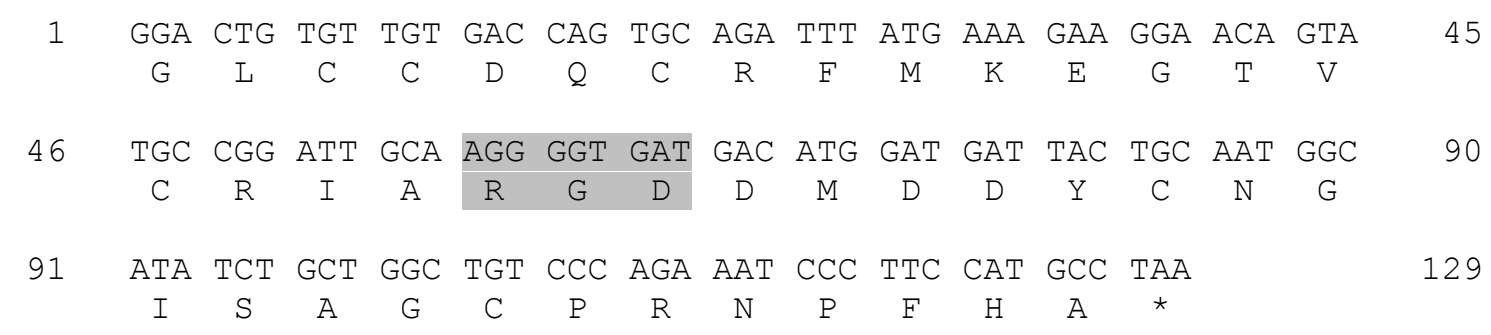

Figura 15: Seqüência de nucleotídeos e aminoácidos deduzido a partir do $\mathrm{pDis} B a(\Delta 1-36)$. O motivo RGD e os códons correspondentes são representados em fundo cinza. O códon de parada é representado por um $(*)$. 


\section{3- Obtenção das Proteínas recombinantes}

As proteínas Dis $B a(\Delta 1-32)$-Trx e $\operatorname{Dis} B a(\Delta 1-36)$-Trx foram expressas em linhagem BL21(DE3) de E. coli, que não apresenta resistência a antibióticos. As culturas foram crescidas em $250 \mathrm{~mL}$ de meio LB acrescido de ampicilina, selecionando os transformantes que contêm o plasmídeo pET 32a. Após indução das culturas com $0,3 \mathrm{mM}$ de IPTG a $37^{\circ} \mathrm{C}$ por 4 horas, as proteínas foram centrifugadas a $4^{\circ} \mathrm{C}$ e o pellet foi ressuspendido em $12 \mathrm{~mL}$ de tampão para coluna de níquel.

As células foram lisadas por sonicação durante 8 minutos, sendo, posteriormente, centrifugadas por 10 minutos a temperatura ambiente, para obtenção das proteínas de interesse na fração solúvel, já que encontram-se em fusão com a tioredoxina, uma proteína predominantemente solúvel.

As amostras do sobrenadante (pré-coluna) foram purificadas em $1 \mathrm{~mL}$ de resina de níquel por afinidade, sendo coletados $10 \mathrm{~mL}$ de void e $10 \mathrm{~mL}$ de lavagem. As proteínas $\operatorname{Dis} B a(\Delta 1-32)-\operatorname{Trx}$ e Dis $B a(\Delta 1-36)-T r x$ foram eluídas em $2 \mathrm{~mL}$ de tampão da coluna de níquel acrescido de $150 \mathrm{mM}$ de imidazol (Figura 16).

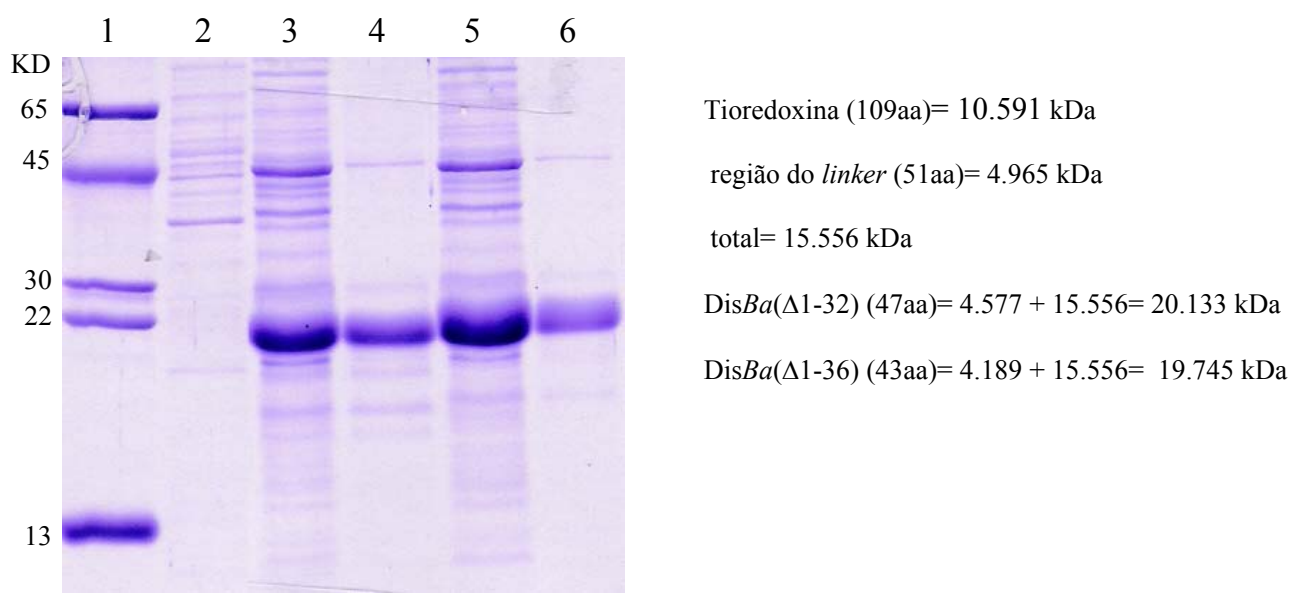

Figura 16: Análise da expressão e purificação em resina de níquel das proteínas Dis $B a(\Delta 1-32)$ e Dis $B a(\Delta 1-36)$ em gel SDS $15 \%$. 1) marcador de peso molecular; 2) B121(DE3) to; 3) sobrenadante $\operatorname{Dis} B a(\Delta 1-32)$; 4) purificação $\operatorname{Dis} B a(\Delta 1-32) ; 5)$ sobrenadante Dis $B a$ $(\Delta 1-36) ; 6)$ purificação $\operatorname{Dis} B a(\Delta 1-36)$. 
As fracões eluídas da coluna de níquel apresentaram alguns contaminantes, mas as bandas de expressão referentes a $\operatorname{Dis} B a(\Delta 1-32)$-Trx e $\operatorname{Dis} B a(\Delta 1-36)$-Trx, que estavam na altura esperada, foram majoritárias. As proteínas de fusão parcialmente purificadas em Níquel foram dialisadas contra tampão EKMax e clivadas com a enzima Enteroquinase Max (Invitrogen). As amostras dialisadas tiveram um rendimento de $0,5 \mathrm{mg} / \mathrm{mL}$, e apresentaram uma clivagem com maior eficiência com $0,5 \mathrm{U}$ da enzima por 18 horas a $4^{\circ} \mathrm{C}$.

Depois da clivagem com a enteroquinase, as proteínas foram separadas em coluna Superdex 75 por exclusão de tamanho. Foram coletadas frações de $1 \mathrm{~mL}$ em um fluxo de 0.5mL/min. Com base na análise dos cromatogramas (Figuras 17, 19), foram escolhidas as frações para análise em géis de tricina (Figuras 18, 20). Devido aos baixos valores de absorbância, as amostras foram concentradas na speedvac até secar. A análise dos géis mostrou que as proteínas $\operatorname{Dis} B a(\Delta 1-32)$ e $\operatorname{Dis} B a(\Delta 1-36)$ eluem da coluna no intervalo das frações 80 a 90.

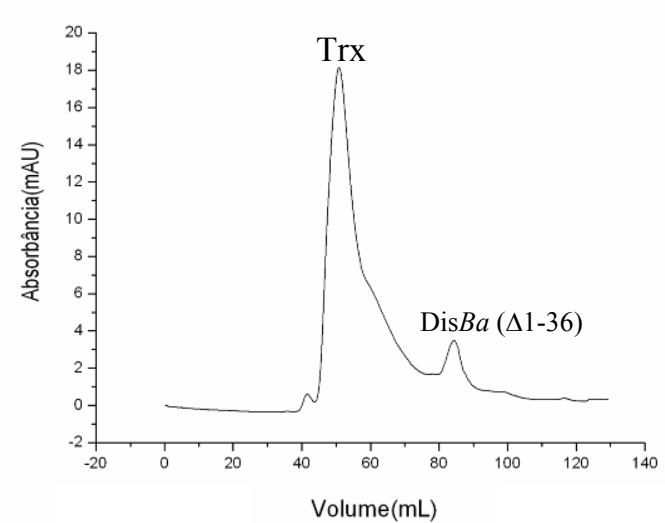

Figura 17: Perfil cromatográfico da purificação da DisBa ( $\Delta 1-36)$ em coluna de gel filtração (Superdex-75).

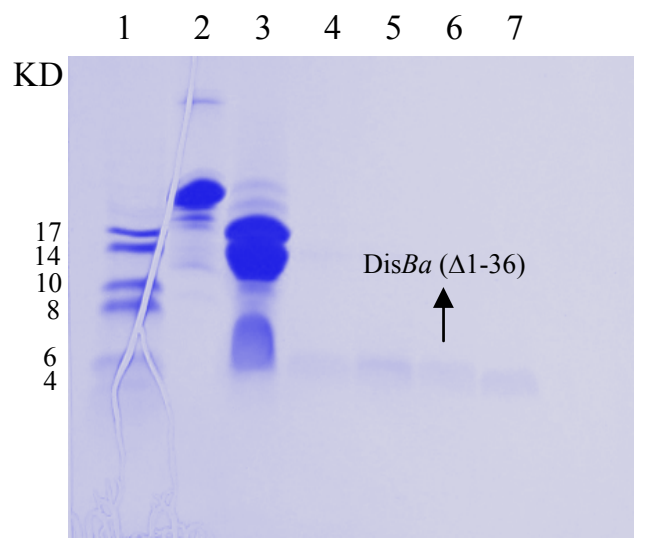

Figura 18: Análise da Purificação da proteína DisBa ( $\Delta 1-36)$ em coluna Superdex 75 em gel de tricina. 1) marcador de peso molecular; 2) Dis $B a$ ( $\Delta 1-36)$ eluída da coluna de níquel; 3 ) Dis $B a$ ( $\Delta 1-36)$ após clivagem com enteroquinase; 4) Fração 84 da purificação da Dis $B a(\Delta 1-36)$ em coluna superdex 75; 5) Fração 87; 6) Fração 89; 7) Fração 90. 


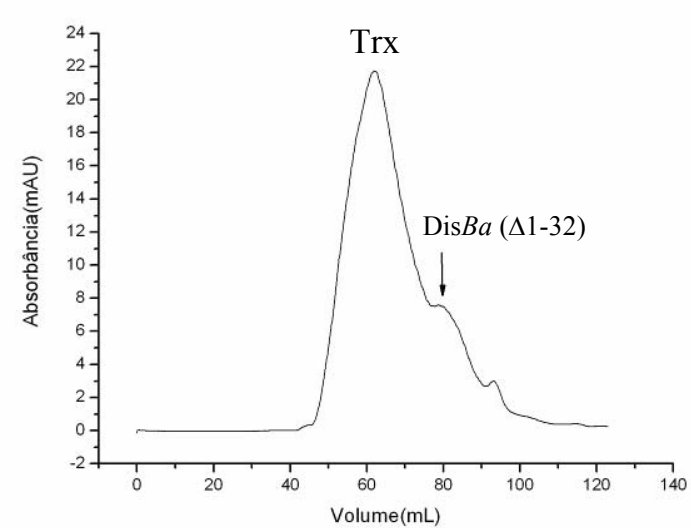

Figura 19: Perfil cromatográfico da purificação da Dis $B a(\Delta 1-32)$ em coluna de gel filtração (Superdex-75).

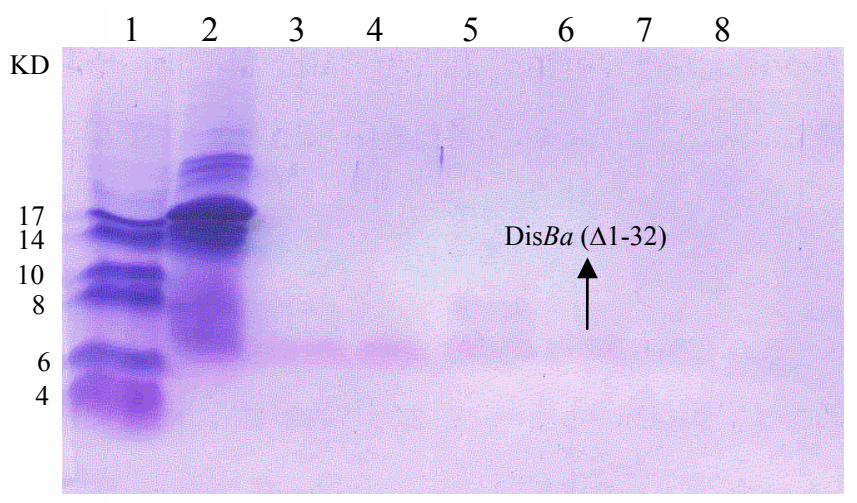

Figura 20: Análise da Purificação da proteína Dis $B a$ $(\Delta 1-36)$ em coluna Superdex 75 em gel de tricina. 1) marcador de peso molecular; 2) Dis $B a(\Delta 1-32)$ após clivagem com enteroquinase; 3) Fração 82 da purificação da Dis $B a(\Delta 1-32)$ em coluna superdex 75; 4) Fração 84; 5) Fração 87; 6) Fração 88; 7) Fração 90; 8) Fração 95.

\section{4- Caracterização das Proteínas por Dot-blot}

As proteínas puras $\operatorname{Dis} B a(\Delta 1-32)$, $\operatorname{Dis} B a(\Delta 1-36)$ e Dis $B a-01$, que serviu como controle positivo, reagiram com o anticorpo anti-Dis $B a-01$ sobre a membrana de nitrocelulose. O anticorpo reconheceu, especificamente, as proteínas como seus antígenos (Figura 21).

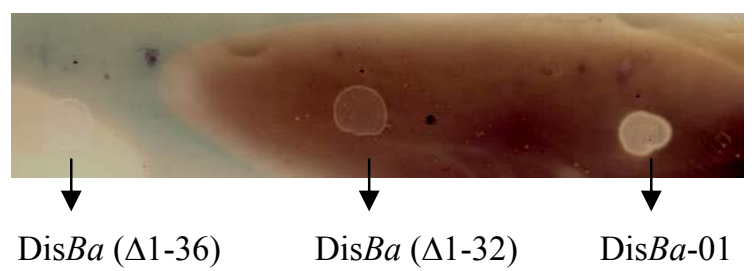

Figura 21: Análise de Dot blot da ligação do anticorpo anti- anti-Dis $B a-01$ com as proteínas Dis $B a(\Delta 1$ 36), Dis $B a(\Delta 1-32)$ e Dis $B a-01$. 


\section{5- Efeito na adesão de células B16F10 à vitronectina}

Após obtenção das proteínas puras, foram conduzidos ensaios de inibição da adesão de células B16F10 de melanoma de camundongo ricas em $\alpha \mathrm{V} \beta 3$, a um conhecido ligante desse receptor, a vitronectina $(1 \mu \mathrm{g} /$ poço). Os ensaios de inibição da adesão celular permitiram verificar a ligação das proteínas em estudo à integrina $\alpha \mathrm{V} \beta 3$. As toxinas $\operatorname{Dis} B a(\Delta 1-32)$ e $\operatorname{Dis} B a(\Delta 1-36)$ foram utilizadas na concentração final de $1 \mu \mathrm{M}$.

Os resultados dos experimentos realizados em triplicata sugerem forte inibição da ligação dessas células à vitronectina, uma vez que a $\operatorname{Dis} B a(\Delta 1-32)$ e $\operatorname{DisBa}(\Delta 1-36)$ apresentaram capacidade de 69,3\% e 70,4\% de inibição da adesão celular, respectivamente. Esses resultados foram bastante expressivos devido a semelhança com o resultado obtido para Dis $B a-01$ que foi de $80 \%$ (Figura 22).

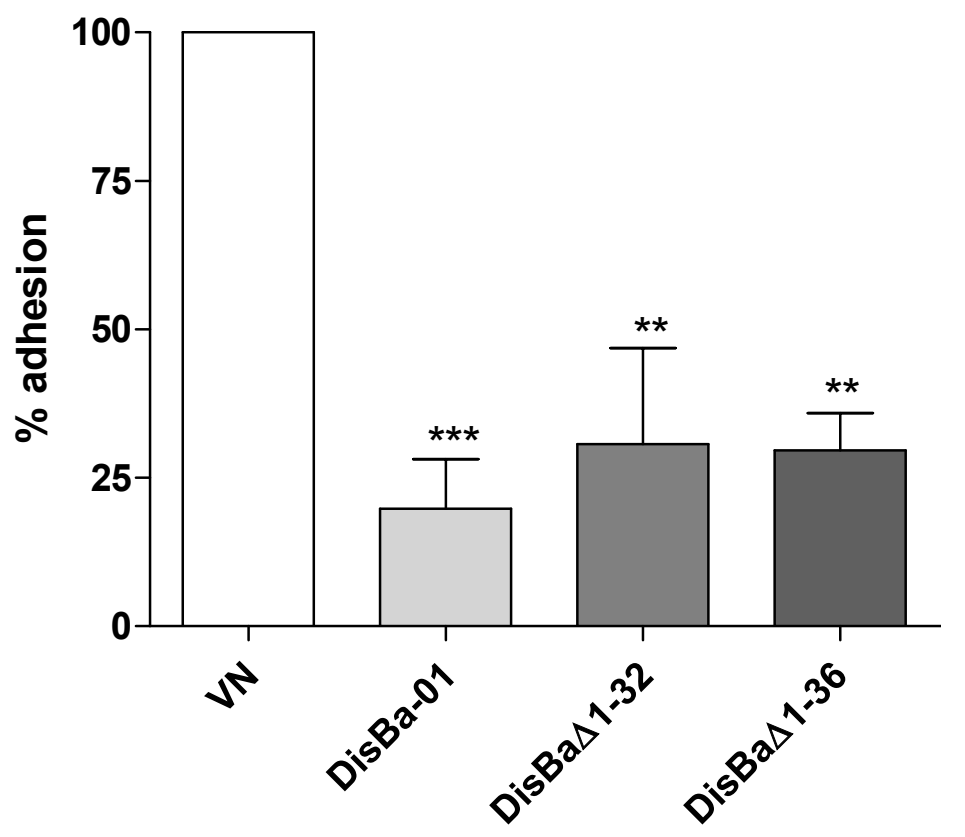

Figura 22: Análise da inibição da adesão de células B16F10 à vitronectina pela $\operatorname{Dis} B a(\Delta 1-32)$ e $\operatorname{Dis} B a(\Delta 1-36)$. 


\section{5 - DISCUSSÕES}

\section{1- Veneno de serpente e novos medicamentos}

O envenenamento por serpentes é um problema sócio-médico de considerável magnitude. Aproximadamente, 2.5 milhões de pessoas são picadas por serpentes anualmente, sendo 100.000 mortes. Entretanto, o veneno é um material biológico que contém diversos componentes de potencial valor terapêutico (KOH; ARMUGAM; JEYASEELAN, 2006).

Este projeto abordou a questão do desenvolvimento de novos fármacos, através do estudo de desintegrinas do veneno de serpente de Bothrops alternatus, pertencente à família Viperidae, encontrada principalmente no norte da Argentina, sul do Paraguai, sul e sudeste do Brasil e em todo o Uruguai (MINISTÉRIO DA SAÚDE, s.d.).

A composição dos venenos de serpente varia entre a família, o gênero e a espécie de serpente. Sendo que as diferenças intra-específicas na composição do veneno são decorrentes da idade, dieta, habitat, dimorfismo sexual do animal, localização geográfica e variação sazonal (FOX et al., 2002; JUNQUEIRA-DE-AZEVEDO et al., 2006; MENEZES et al., 2005).

Os venenos de serpentes contêm misturas complexas de moléculas bioativas com importantes atividades farmacológicas, incluindo compostos orgânicos e minerais, pequenos peptídeos e proteínas (BJARNASON; FOX, 1994; MARKLAND, 1998). O veneno de serpentes da família Viperidae contém diferentes proteínas que interferem na coagulação, hemostasia e no reparo tecidual (CALVETE et al., 2005). Diversas proteínas de veneno têm sido usadas na pesquisa pré-clinica para examinar seus possíveis potenciais terapêuticos para desenvolvimento de novos fármacos. Recentemente, as desintegrinas estão sendo usadas como protótipos estruturais para desenhos e desenvolvimento de peptídeos e não-peptídeos 
miméticos do motivo RGD, visando à produção de novos fármacos contra a trombose e outros problemas cardiovasculares. São exemplos dessas pequenas moléculas a eptifibatide (Integrilin), derivada do veneno de serpente $S$. miliarus barbouri, e a tirofiban (Aggrastat), derivada do veneno de Echis carinatus. Esses fármacos agem como anticoagulantes do sangue, inibindo o fibrinogênio. Estudos clínicos envolvendo pacientes com Síndrome Coronária Aguda (SCA), conhecida como infarto do miocárdio ou angina instável, têm demonstrado uma redução significativa na progressão da trombose coronária arterial, através de uma terapia combinando a aspirina, heparina, bem como a tirofiban ou a eptifibatide. A Síndrome Coronária Aguda envolve lesão endotelial, trombose e isquemia (CHUNG et al., 2007; GIBSON et al., 2007; MARCINKIEWICZ, 2005; KOH; ARMUGAM; JEYASEELAN, 2006).

As desintegrinas foram primeiramente descritas como potentes inibidores da agregação plaquetária. Muitas desintegrinas contêm a seqüência adesiva RGD, responsável pela ligação à integrinas $\alpha_{\mathrm{IIb}} \beta_{3}$ na superfície de plaquetas, bloqueando a ação do fibrinogênio (GOULD et al., 1990). Entretanto, estudos demonstraram que as desintegrinas podem ter aplicações biomédicas em patologias como derrame cerebral, infarto, diabetes e câncer (HUANG et al., 1991; MARCINKIEWICZ et al., 2003; NIEWIAROWSKI et al., 1989; SHEU et al., 1992). Pesquisas recentes mostraram que desintegrinas RGD agem diretamente em diversas células endoteliais, bloqueando a integrina $\alpha \mathrm{V} \beta 3$ e inibindo sua adesão à matriz extracelular, desempenhando um papel importante na prevenção da angiogênese tumoral e metástase (KOH; ARMUGAM; JEYASEELAN, 2006).

\subsection{1- Angiogênese}

A angiogênese é o processo de formação de novos vasos sanguíneos a partir de células endoteliais, fundamental no desenvolvimento de órgãos, cicatrização de ferimentos, processos 
inflamatórios, desenvolvimento e disseminação dos tumores. A angiogênese e a metástase tumoral estão funcionalmente relacionadas, pois participam dos seguintes eventos fisiopatológicos: migração celular, proteólise tecidual e proliferação celular (Liotta, Steeg, Steller-Stevenson, 1991). Alvos anti-angiogênicos têm sido explorados para tratamento e prevenção do câncer e da metástase. A integrina $\alpha \mathrm{V} \beta 3$, conhecida como receptor de vitronectina, é altamente expressa em células endoteliais ativadas e em células tumorais, mas não está presente nas células endoteliais em repouso e em sistemas orgânicos normais, o que a torna um alvo adequado para a terapia anti-angiogênica tumoral e anti-metastática. Diversos antagonistas para tratamento do câncer vêm sendo testados, como o MEDI-522 (anticorpo monoclonal de humano anti-integrina $\alpha \mathrm{V} \beta 3$ ), Cilengitide (peptídeo cíclico antagonista das integrinas $\alpha \mathrm{V} \beta 3$ e $\alpha \mathrm{V} \beta 5$ ) e pequenas moléculas de RNA de interferência (siRNA), que especificamente silenciam a integrina $\alpha \mathrm{V} \beta 3$, diminuindo o tumor. A combinação da terapia anti-integrina $\alpha \mathrm{V} \beta 3$ e outras abordagens terapêuticas (como quimioterapia, radioterapia e terapia genética) são aplicadas para potencial tratamento do câncer (WEIBO; XIAOYUAN, 2006).

A busca por novos fármacos no combate ao câncer é muito importante, tendo em vista que o quadro atual é caracterizado pela existência de tratamentos de elevado custo e índice terapêutico relativamente reduzido. Há diversas classes farmacológicas disponíveis de agentes quimioterápicos para tratamento do câncer, mas nenhuma delas tem se mostrado capaz de erradicar as células cancerosas sem afetar os tecidos normais.

\section{2- A escolha dos mutantes da DisBa-01}

A proteína Dis $B a-01$, recentemente estudada, é uma desintegrina RGD recombinante de tamanho médio composta por 78 resíduos de aminoácidos, a qual acredita-se que a forma 
nativa seja gerada no veneno de Bothrops alternatus à partir de uma metaloproteinase da classe PII de metaloproteases. Sua seqüência é rica em cisteínas, e é prevista a formação de 6 pontes dissulfeto. Essa toxina possui alta afinidade pelas integrinas $\alpha \mathrm{V} \beta 3$ e $\alpha \operatorname{Ilb} \beta 3$, envolvidas na formação de tumores e trombose, respectivamente (RAMOS, 2005). O estudo de variantes estruturais da Dis $B a-01$ pode contribuir para o melhor entendimento das porções moleculares responsáveis por sua interação com integrinas e por seus efeitos. A análise do modelo para a estrutura tridimensional da DisBa-01 e do complexo $\alpha \mathrm{V} \beta 3$-Dis $B a-01$ prediz a ausência de interação da porção N-terminal da DisBa-01 na ligação desta com a integrina. Em vista dessa predição, foram desenvolvidos dois ligantes estruturalmente reduzidos a partir da Dis $B a-01$ denominados $\operatorname{Dis} B a(\Delta 1-32)$ e $\operatorname{Dis} B a(\Delta 1-36)$. Dis $B a(\Delta 1-32)$ apresenta o N-terminal iniciando no resíduo 33 da seqüência da $\operatorname{Dis} B a-01$ e a molécula $\operatorname{Dis} B a(\Delta 1-36)$ inicia-se no resíduo 37.

A decisão de quantos resíduos seriam eliminados da região N-terminal da molécula de Dis $B a-01$ foi tomada levando-se em consideração que não queriamos uma molécula de massa molecular semelhante a da DisBa-01. Isto significava que precisaríamos eliminar uma quantidade razoavel de resíduos do N-terminal. As desintegrinas seguem um padrão característico de pontes dissulfeto e podemos prever as pontes dissulfetos nas moléculas Dis $B a-01$, Dis $B a(\Delta 1-32)$ e Dis $B a(\Delta 1-36)$ como mostrado na Figura 23, seguindo esse padrão descrito na literatuta (Kim et al., 2005). 

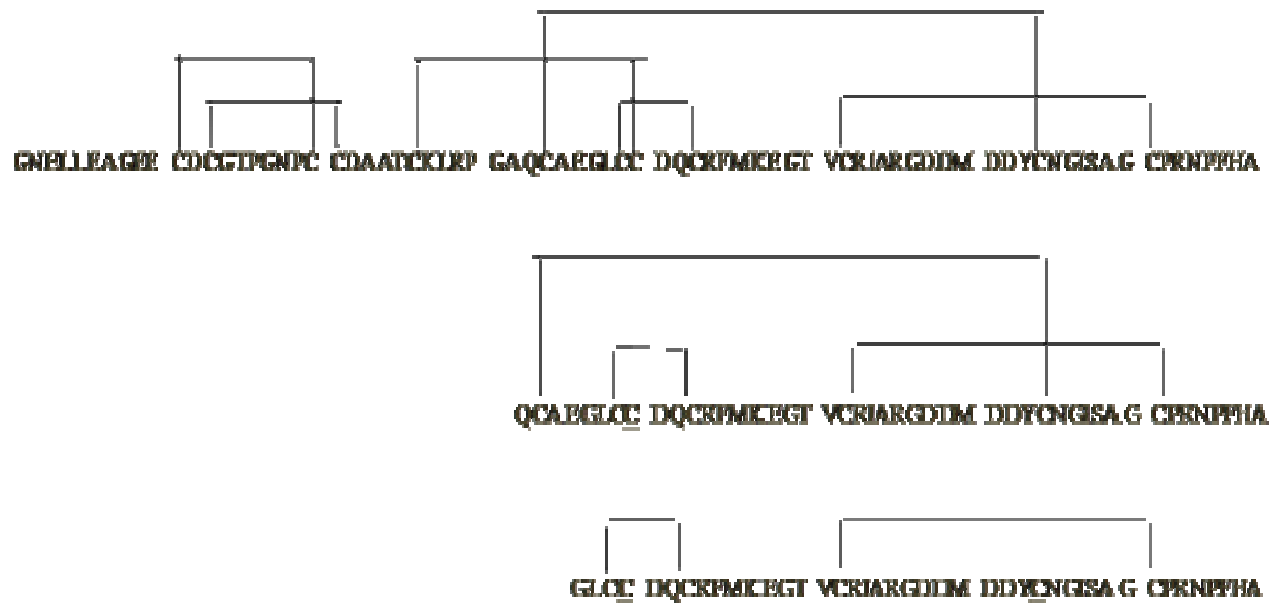

Figura 23: Pontes disulfeto previstas para as moléculas Dis $B a-01$, Dis $B a(\Delta 1-32)$ e $\operatorname{Dis} B a(\Delta 1-36)$.

Segundo o seqüenciamento do DNA a previsão das pontes dissulfetos da DisBa-01 (Figura 23) mostra que a molecula é constituída por seis (6) pontes dissulfeto. A molécula $\operatorname{Dis} B a(\Delta 1-32)$ apresenta 3 pontes dissulfeto e um resíduo de cisteína livre, e a molécula $\operatorname{Dis} B a(\Delta 1-36)$ apresenta 2 pontes dissulfeto e dois (2) resíduos de cisteína livres.

\section{3- Obtenção das proteínas recombinantes}

Os oligonucleotídeos foram desenhados de forma que os DNAs fossem subclonados no vetor pET32a, que permite a expressão da proteína de interesse em fusão com a proteína tiorredoxina e o peptídeo de 6 histidinas - Trx.Tag. Os DNAs pDis $B a(\Delta 1-32)$ e pDis $B a(\Delta 1$ 36), submetidos a PCR resultaram na amplificação de um fragmento, de aproximadamente, $141 \mathrm{pb}$ e $129 \mathrm{pb}$, respectivamente, confirmando o sucesso da subclonagem.

A análise do seqüenciamento dos plamídeos $\mathrm{pDis} B a(\Delta 1-32)$ e $\mathrm{pDis} B a(\Delta 1-36)$ mostrou que a junção gene-vetor pET32a estava correta, em fase de leitura com a His Tag e que havia 
integridade do inserto, descartando, portanto, a possibilidade de uma eventual mutação. Esse resultado viabilizou a etapa de expressão das proteínas.

A produção de proteínas em $E$. coli através da engenharia genética, tem permitido a obtenção de proteínas para caracterização bioquímica, produção de anticorpos, determinação da estrutura tridimensional, entre outros (RÜCKER et al., 2001). Em adição, a expressão de proteínas heterólogas em fusão com a cauda de histidina (His Tag) tem possibilitado a obtenção de proteínas com grau de pureza adequado para ensaios envolvendo a compreensão da estrutura e função da proteína alvo (SAMBROOK; RUSSEL, 2001).

Em vista disso, para os experimentos de expressão das proteínas mutantes, foi utilizada a linhagem BL21(DE3) de E. coli, possibilitando a superexpressão das proteínas em fusão com a tiorredoxina, que é responsável pela solubilidade e estabilidade das proteínas alvo. A tioredoxina possui massa molecular aparente de 12757,4 $\mathrm{kDa}$ e representa dois terços da proteína total, já as proteínas $\operatorname{Dis} B a(\Delta 1-32)$ e $\operatorname{Dis} B a(\Delta 1-36)$, com massa molecular aparente de 4.627 e $5.058 \mathrm{kDa}$, respectivamente, representam um terço da proteína total, sendo, portanto, expressas na forma solúvel. No entanto, a Dis $B a-01$, em estudos anteriores, foi clonada no pET28a e expressa na forma insolúvel, sendo solubilizada por agente caotrópico (Uréia 6M). As proteínas insolúveis formam corpos de inclusão (agregado protéico insolúvel) que torna o produto expresso menos tóxico ao hospedeiro e está em maior parte protegida da digestão proteolítica (SAMBROOK; RUSSEL, 2001). O aspecto negativo é que nem sempre é possível fazer o renovelamento da proteína para sua conformação nativa a partir dos corpos de inclusão, e quando os experimentos envolvem estudos estruturais ou funcionais, a melhor opção é obter a expressão na forma solúvel.

A solubilidade das proteínas $\operatorname{Dis} B a(\Delta 1-32)$-Trx e $\operatorname{Dis} B a(\Delta 1-36)$-Trx, possibilitou os ensaios de purificação por cromatografia de afinidade em coluna de níquel (Ni-NTA). Durante a purificação observou-se que ao passar o sobrenadante pela coluna, a resina de 
níquel de cor originalmente azul, passou a ter a coloração esverdeada, indicando que a fusão ficou retida na resina de afinidade. As proteínas foram eluídas em tampão da coluna com 150 $\mathrm{mM}$ de imidazol, o que confere a alta afinidade das proteínas pela resina, fornecida pela exposição do sítio de His Tag da proteína.

\section{4- Clivagem das proteínas de fusão com a enteroquinase}

A presença do sitio de clivagem reconhecido pela enteroquinase presente no vetor pET32a, permitiu separar as fusões tiorredoxina e os mutantes Dis $B a(\Delta 1-32)$ e Dis $B a(\Delta 1-36)$. Para isso fez-se a digestão proteolítica com a enzima enteroquinase, visto que se tomou o cuidado inicial de analisar se havia algum sítio interno de reconhecimento para proteases na seqüência primária de aminoácidos das proteínas $\operatorname{Dis} B a(\Delta 1-32)$ e $\operatorname{Dis} B a(\Delta 1-36)$. A análise in silico revelou que na seqüência de aminoácidos das proteínas não há seqüências de reconhecimento para a enzima enteroquinase. No entanto, após a clivagem com a protease enteroquinase observou-se que ocorreram algumas proteólises inespecíficas em todas as condições testadas, devido à degradação dos contaminantes presentes nas amostras eluídas da resina de níquel. A enteroquinase reconhece a seqüência AspAspAspAspLys $\downarrow$, mas dependendo da conformação do substrato pode reconhecer outros residuos básicos formando o então denominado sitio de clivagem secundário (STEVENS, 2000).

A escolha da cromatografia mais eficiente para a purificação das amostras clivadas foi feita com base na análise in silico (www.expasy.ch) das moléculas Dis $B a(\Delta 1-32)$, Dis $B a$ $(\Delta 1-36)$ e Tioredoxina, que apresentaram os seguintes parametros:

$\underline{\operatorname{Dis} B \boldsymbol{B}(\Delta 1-32)}-46$ resíduos de aminoácidos QCAEGLCCDQ CRFMKEGTVC RIARGDDMDD YCNGISAGCP RNPFHA Massa molecular de 5058,7 e pI teórico de 4,95. 
$\underline{\operatorname{Dis} B \boldsymbol{a}(\Delta 1-36)}-42$ resíduos de aminoácidos

\section{GLCCDQCRFM KEGTVCRIARGDDMDDYCNG ISAGCPRNPF HA}

Massa molecular de 4627,2 e pI teórico de 5,50

Tioredoxina- 109 resíduos de aminoácidos

G Q V S V E E L F Q L T F R Q C T H F G C R H F T V F E Q Q Q S R D T T D A IF R R S A R V L I D Q F C N G Q F A L IF V S F I Q N R G D H F A T A P L C P E I D D R P V R F E Y I R V K T V V S Q V N N F I A H

Massa molecular de 12757,4 e pI teórico: 6,45

As proteínas podem ser separadas de acordo com a sua carga (cromatografia de troca iónica), sua hidrofobicidade (cromatografia de interacção hidrofóbica), seu tamanho (filtração em gel) ou pela sua capacidade de se ligar a grupos químicos particulares.

O pI é o valor de pH onde uma molécula, por exemplo, um aminoácido ou uma proteína, apresenta carga elétrica líquida igual a zero. O pI é o pH no qual há equilíbrio entre as cargas negativas e positivas dos grupamentos iônicos de um aminoácido ou de uma proteína. Uma vez que o pI das proteínas mutantes e da tiorredoxina apresentam valores próximos, a cromatografia de troca iónica seria inadequada para separação destas proteínas. Sendo assim, as proteínas podem ser purificadas utilizando-se a cromatografia por exclusão de tamanho, uma vez que a massa molecular da DisBa ( $\Delta 1-32)$ e $\operatorname{Dis} B a(\Delta 1-36)$ equivale à metade da massa da tioredoxina.

\subsection{1- Cromatografia por gel filtração}

A cromatografia de filtração em gel separa as proteínas com base no seu tamanho. A coluna é constituída por uma matriz de pequenas esferas porosas empacotadas. Ao fazer 
passar a solução de proteínas pela matriz da coluna, as moléculas pequenas entram nos poros das esferas demorando a atravessá-los, enquanto que as grandes passam entre as esferas, sendo separadas primeiro.

A coluna utilizada para realizar os experimentos de purificação foi a Superdex 75,

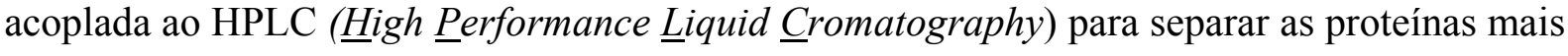
rapidamente do que os métodos convencionais, com estruturas e tamanhos muito semelhantes.

A análise do cromatograma das purificações das $\operatorname{Dis} B a(\Delta 1-32)$ e $\operatorname{Dis} B a(\Delta 1-36)$ (Figuras 17 e 19) mostrou dois picos principais de absorbância, um correspondente à tiorredoxina, entre as frações 40 e 70, e o outro correspondente às proteínas em estudo, entre as frações 80 e 90 . No entanto, a purificação tem um rendimento baixo, sendo necessário concentrar as amostras para caracterização das proteínas e realização dos ensaios biológicos.

\section{5- Caracterização das proteínas DisBa ( $\Delta 1-32)$ e Dis $B a(\Delta 1-36)$}

O seqüenciamento das proteínas ainda não pode ser realizado devido à dificuldade para transferência das bandas das proteínas do gel de tricina para uma membrana de PVDF, em vista do tipo de gel e da baixa concentração das proteínas.

Uma forma de caracterização das proteínas mutantes foi o ensaio imunológico do Dotblot, onde as proteínas DisBa ( $\Delta 1-32)$ e $\operatorname{Dis} B a(\Delta 1-36)$ reagiram especificamente com o anticorpo anti-DisBa-01. O dot-blot é um ensaio altamente sensível, reforçando a especificidade e as propriedades ligantes das proteínas identificadas. Alguns trabalhos utilizam o dot-blot para seleção e detecção de metaloproteases. Como exemplos, a identificação do complexo GST-RHO (formado pela GST e a Rhodostomin RGD) que se liga especificamente ao anticorpo anti-integrina $\beta 3$ e a detecção das ADAMs 10, expressas na pele, condrócitos e coração, e das ADAMs 33 localizadas em fluidos lavado broncoalveolar 
(BAL) em pacientes com asma, utilizando anticorpos contra o domínio catalítico (CHANG et al., 2001; DAGONEAU et al., 2004; LEE et al., 2006).

\section{6- Efeitos anti-tumorais}

A invasão do tumor e metástase são processos que letalmente espalham as células cancerosas por todo o corpo, e estão estreitamente relacionados à interação adesiva entre as células e a matriz extracelular. Durante formação do tumor e metástase, as células tumorais podem causar a retração de células endoteliais, expondo a membrana basal subendotelial e permitindo eficientemente a adesão das células tumorais às proteínas da matriz extracelular. Estas proteínas da matriz promovem a adesão celular pela ligação a receptores específicos das células da superfície, incluindo membros da família integrina (HYNES, 1987; RUOSLAHTI; PIERSCHBACHER, 1987; ZETTER, 1990).

A integrina $\alpha \mathrm{V} \beta 3$, utilizada nesse estudo, é um receptor celular que se liga à fibronectina e vitronectina (ECM), sendo importante na angiogênese e metástase. As desintegrinas são inibidores específicos das integrinas, podendo impedir a adesão e invasão celular em diferentes tumores (MARKLAND, 1998). A echistatin, em ensaios in vitro, inibiu células B16-BL6 de melanoma de camundongo à fibronectina, vitronectina e laminina (STAIANO et al., 1995). SOSZKA et al. (1991) mostrou que a albolabrin, peptídeo isolado de veneno de Trimeresurus albolabris, inibe a aderência de células de melanoma de camundongo B16F10 às proteínas da matriz extracelular. Muitas desintegrinas, incluindo a contortrostatin, triflavin, rhodostomin e salmosin foram testadas in vitro e in vivo, como também eficazes agentes anti-tumorais. (KANG et al., 2000; SHEU et al., 1992; SHEU et al., 1994; SWENSON et al., 2004; TRIKHA et al., 1994; WIEDLE et al., 1999; ZHOU et al., 2000). 
$\mathrm{O}$ presente projeto, sugere que as moléculas $\operatorname{Dis} B a(\Delta 1-32)$ e $\operatorname{Dis} B a(\Delta 1-36)$, derivadas da desintegrina-RGD Dis $B a-01$, inibem a integrina $\alpha \mathrm{V} \beta 3$, presente em células de melanoma de camundongo B16F10, que expressa altos níveis da integrina. O domínio RGD se liga às integrinas e impede a ligação, mediada por integrinas, das células aos ECM. Os ensaios de inibição da adesão celular mostraram que $1 \mu \mathrm{M}$ das proteínas Dis $B a(\Delta 1-32)$ e Dis $B a(\Delta 1-36)$ é suficiente para inibir $70 \%$ da adesão celular à vitronectina, valor semelhante ao obtido pela DisBa-01 (80\%).

Esse resultado comprova a ausência de interação da região N-terminal da DisBa-01 na ligação com a integrina $\alpha \mathrm{V} \beta 3$. Esse dado é muito importante, podendo ampliar as buscas por novas construções da molécula Dis $B a-01$, ainda mais reduzidas, como potenciais terapêuticos contra o câncer. 


\section{6- CONCLUSÕES}

Com base nos resultados discutidos, pode-se concluir que:

$\checkmark$ Os genes que codificam para as proteínas $\operatorname{Dis} B a(\Delta 1-32)$ e $\operatorname{Dis} B a(\Delta 1-36)$ foram subclonados no vetor pET 32a com sucesso.

$\checkmark$ Estas proteínas foram expressas em culturas BL21(DE3) de E. coli na forma solúvel em fusão com a tiorredoxina, e purificadas em coluna de Níquel.

$\checkmark$ A clivagem das proteínas de fusão com a enteroquinase foi eficiente, separando a tiorredoxina das proteínas em estudo.

$\checkmark$ A purificação por cromatografia de filtração a gel, possibilitou a obtenção das proteínas $\operatorname{Dis} B a(\Delta 1-32)$ e $\operatorname{Dis} B a(\Delta 1-36)$. No entanto, uma cromatografia por fase reversa é necessária para melhorar a pureza das amostras.

$\checkmark$ As proteínas $\operatorname{Dis} B a(\Delta 1-32)$ e $\operatorname{Dis} B a(\Delta 1-36)$ foram testadas e apresentaram capacidade de $69,3 \%$ e 70,4\% de inibição da adesão celular à vitronectina, respectivamente, valores próximos ao obtido com a Dis $B a-01(80 \%)$. 


\section{7- PERSPECTIVAS}

As pesquisas realizadas com as proteínas isoladas de veneno de serpente têm sido uma área promissora, uma vez que muitos destes compostos vêm sendo utilizados para o desenvolvimento de medicamentos contra a trombose e câncer. A procura de outros componentes de veneno de serpente, assim como de novas substâncias é justificada, pois fica cada vez mais evidente a necessidade de coquetéis de drogas que atuem em diversos pontos do processo hemostático e da metástase.

Os resultados dos ensaios de inibição da adesão de célula de melanoma sugerem que as moléculas $\operatorname{Dis} B a(\Delta 1-32)$ e $\operatorname{Dis} B a(\Delta 1-36)$ são capazes de inibir a metástase e a angiogênese. $\mathrm{O}$ efeito inibitório sobre a metástase pode estar ligada ao bloqueio da integrina $\alpha \operatorname{IIb} \beta 3$, tendo em vista que algumas células tumorais expressam essa integrina e se agregam a plaquetas, protegendo-as durante o transporte na circulação e favorecendo o processo de arresting anterior a extravasamento e invasão de um novo tecido. Esses dados implicam na continuação dos estudos de mutantes da Dis $B a-01$ para o desenvolvimento de agentes anticancerígenos. Certos estudos são importantes para complementar e gerar avanços no trabalho desenvolvido.

Os ensaios de inibição da adesão celular deveriam ser realizados com outras linhagens de células cancerosas, como HMEC-1, para elucidar a hipótese de uma interação entre o motivo RGD das Dis $B a-01$ e a integrina $\alpha \mathrm{V} \beta 3$. Também poderiam ser utilizados ligantes da integrina $\alpha \mathrm{V} \beta 3$ mais específicos, como o fator de von Willebrand (vWF) ou anticorpos específicos. Seria interessante a realização de estudos similares envolvendo outras integrinas, como a $\alpha \mathrm{V} \beta 1$, que é amplamente distribuída em uma variedade de células, importantes na adesão celular à matriz extracelular, assim como na formação de tecidos e órgãos durante o desenvolvimento embrionário (HYNES, 1996). 
Estudos de inibição da agregação plaquetária foram iniciados e resultados preliminares mostraram que as proteínas $\operatorname{Dis} B a(\Delta 1-32)$ e $\operatorname{Dis} B a(\Delta 1-36)$ não foram capazes de inibir a agregação plaquetária induzida por ADP em plasma rico em plaquetas (PRP) humano. Sendo assim, os ensaios precisam ser refeitos, com amostras contendo um maior grau de pureza, para que se possam obter dados conclusivos. Se esses resultados se confirmarem, podem ser muito importantes uma vez que mostraria a seletividade e especificidade das proteínas Dis $B a$ $(\Delta 1-32)$ e $\operatorname{Dis} B a(\Delta 1-36)$ pela integrina $\alpha \mathrm{V} \beta 3$ expressas em células tumorais.

Os ensaios de inibição da adesão celular e da agregação plaquetária realizados in vitro, precisam ser confirmados por meio de experimentos in vivo, para serem validados.

O seqüenciamento da porção N-terminal das proteínas $\operatorname{Dis} B a(\Delta 1-32)$ e $\operatorname{Dis} B a(\Delta 1-36)$ ainda não foi realizado, no entanto, seria importante conseguir amostras mais puras. Para isso, as amostras das proteínas recombinantes purificadas em coluna de filtração a gel, deveriam ser, posteriormente, purificadas por cromatografia por fase reversa. Essa cromatografia é utilizada para análise de pequenas moléculas, pois possibilita uma fácil resolução de picos ocultos e sobrepostos, conduzindo a uma redistribuição das posições dos picos em muitas separações de amostras complexas. A escolha da fase é determinada pelo peso molecular e hidrofobicidade do peptídeo. A cromatografia por fase reversa, junto com espectrometria de massa, tem se tornado uma valiosa chave para determinação e análise da estrutura detalhada de peptídeos e proteínas.

A determinação da estrutura das formas mutantes reduzidas da DisBa-01 e da molécula inteira, livres e complexadas à integrinas, utilizando a técnica de NMR e cristalografia associada à difração de raios $\mathrm{X}$, forneceria valiosas informações sobre as características de interações de desintegrinas RGD à integrinas, favorecendo a construção de peptídeos ou fármacos para o tratamento do câncer e da trombose. 


\section{REFERÊNCIAS}

ADLER, M. et al. Solution structure of kistrin, a potent platelet aggregation inhibitor and GP IIb-IIIa antagonist. Science, v. 253, n. 5018, p. 445-448, 1991.

ARNAOUT, M. A. Leukocyte adhesion molecules deficiency: its structural basis, pathophysiology and implications for modulating the inflammatory response. Immunol. Rev., v. 114, p. 145-180, 1990.

BARAMOVA, E.N. et al. Degradition of extracellular matrix proteins by hemorrhagic metalloproteinases. Arch. Biochem. Biophys., v. 275, p. 63-71, 1989.

BARREIRO, E. J.; FRAGA, C. A. M. Planejamento racional baseado no mecanismo de ação: fármacos inteligentes. In: Química Medicinal: as bases moleculares da ação de fármacos. Porto Alegre - RS: ARTMED Editora S.A. 2001. cap. 3, p. 83-124.

BEVIGLIA, L.; STEWART, G. J.; NIEWIAROWSKI, S. Effect of four disintegrins on the adhesive and metastatic properties of B16F10 melanoma cells in a murine model. Oncol.Res., v. 7, n. 1, p. 7-20, 1995.

BILATO, C. et al. The inhibition of vascular smooth muscle cell migration by peptide and antibody antagonists of the alphavbeta3 integrin complex is reversed by activated calcium/calmodulin- dependent protein kinase II. J. Clin. Invest, v. 100, n. 3, p. 693-704, August 1997.

BILGRAMI, S. et al. Crystal structure of schistatin, a disintegrin homodimer from saw-scaled viper (Echis carinatus) at 2.5 A resolution. J. Mol. Biol., v. 341, n. 3, p. 829-837, 2004.

BJARNASON, J. B. N.; FOX, J. W. Hemorrhagic metalloproteinases from snake venoms. Pharmac. Ther., v. 62, p. $325-372,1994$.

CALVETE, J.J. et al. The disulfide bond pattern of catrocollastatin C, a disintegrin/cysteine-rich protein isolated from Crotalus atrox venom. Protein Sci., v. 9, p. 1365-1373, 2000a.

CALVETE, J. J. et al. Disulfide bond pattern and molecular modelling of the dimeric disintegrin EMF-10, a potent and selective integrin $\alpha 5 \beta 1$ antagonist from Eristocophis macmahoni venom. Biochem. J., v. 345, p. 573-581, 2000b.

CALVETE, J. J. et al. Snake venom disintegrins: novel dimeric disintegrins and structural diversification by disulphide bond engineering. Biochem.J., v. 372, n. Pt 3, p. 725-734, 2003.

CALVETE, J.J. et al. Snake venom disintegrins: evolution of structure and function. Toxicon, v. 45, n.8, p. 1063-1074, June 2005.

CHANG, C. P. et al. Positional importance of Pro53 adjacent to the Arg49-Gly50-Asp51 sequence of rhodostomin in binding to integrin alphalIbbeta3. Biochem. J., v. 357, n. Pt 1, p. 57-64, 2001. 
CHIANG, H. S.; YANG, R. S.; HUANG, T. F. The Arg-Gly-Asp-containing peptide, rhodostomin, inhibts in vitro cell adhesion to extra cellular matrices and platelet aggregation caused by saos- 2 human osteosarcoma cells. Br. J. Cancer, v. 71, n.2, p. 265-270, 1995.

CHUNG, T.L. et al. Prevention of microsurgical anastomotic thrombosis using aspirin, heparin, and the glycoprotein IIb/IIIa inhibitor tirofiban. Plast. Reconstr. Surg., v.120, n.5, p. 1281-1288, 2007.

COOKE, R.M. et al. Nuclear magnetic resonance studies of the snake toxin echistatin. Eur. J. Biochem., p. 202323, 1991.

CUSHMAN, D.W. et al. Development and design of specific inhibitors of angiotensin-converting enzyme. Am. J. Cardiol., v.49, n. 6, p. 1390-1394, April 1982.

DAGONEAU, N. et al. ADAMTs10 mutations in autosomal recessive weill-marchesani syndrome. Am. J. Hum. Genet., v. 75, p. 801-806, 2004.

DANEN, E. H. et al. The disintegrin eristostatin interferes with integrin alpha 4 beta 1 function and with experimental metastasis of human melanoma cells. Exp. Cell Res., v. 238, n. 1, p. 188-196, 1998.

DENNIS, M.S. et al. Platelet glycoprotein IIb-IIIa protein antagonists from snake venoms: evidence for a family of platelet-aggregation inhibitors. Proc. Natl. Acad. Sci.., v.87, n.7, p. 2471-2475, 1990.

DENNIS, M. S.; CARTER, P.; LAZARUS, R. A. Binding interactions of kistrin with platelet glycoprotein IIbIIIa: analysis by site-directed mutagenesis. Proteins, v. 15, n. 3, p. 312-321, 1993.

DZAMBA, B.J.;, BOLTON, M.A.; DESIMONE, D.W. The integrin family of cell adhesion molecules. Frotiers in Molecular Biology, Cell Adhesion, Oxford, n. 4, p. 100-154, 2001.

FOX, J.W. et al. Role of Discovery Science in Toxinology: examples in venom proteomics. In: MENEZ, A. (ed.). Perspectives in Molecular Toxinology. West Sussex, UK,John Wiley \& Sons Ltd. 2002. p. 97-108.

FUJII, Y. et al. Crystal structure of trimestatin, a disintegrin containing a cell adhesion recognition motif RGD. J. Mol. Biol., v. 332, n. 5, p. 1115-1122, 2003.

GAN, Z. R. et al. Echistatin: a potent platelet aggregation inhibitor from the venom of the viper, Echis carinatus. J. Biol. Chem., v. 263, p. 19827-19832, 1988.

GIANCOTTI, F. G. ; RUOSLAHTI, E. Integrin signaling. Science, v. 285, n. 5430, p. 1028-1032, 1999.

GIBSON, C.M. et al. Impact of iodinated contrast injections on percent diameter coronary arterial stenosis and implications for trials of intracoronary pharmacotherapies in patients with ST-elevation myocardial infarction. Am. J. Cardiol., v. 100, n.1, p. 13-17, July 2007.

GOULD, R. J. et al. Disintegrins: a family of integrin inhibitory proteins from viper venoms. Proc. Soc. Exp. Biol. Med, v. 195, n. 2, p. 168-171, 1990. 
GRAMS F. et al. Activation of snake venom metalloproteinases by a cysteine switch-like mechanism. FEBS Lett, v. 335, p. 76-80, 1993.

HITE, L.A. et al. cDNA sequences for four snake venom metalloproteinase: structure, classification and their relationship to mammalian reproductive proteins. Arch. Biochem. Biophys. v. 308, p. 182-191, 1994.

HUANG T.F. et al. A low molecular weight peptide inhibiting fibrinogen interaction with platelet receptors expressed on glycoprotein IIb/IIIa complex. J. Biol. Chem., v. 262, p. 16157, 1987.

HUANG, T.F.; SHEU, J.R.; TENG, C.M. Mechanism of action of a potent antiplatelet peptide, triflavin from Trimeresurus flavoviridis snake venom. Thromb. Haemost. v. 66, p. 489-493, 1991.

HUANG, T.F.; NIEWIAROWSKI, S. Disintegrins: the naturally-occurring antagonists of platelet fibrinogen receptor. J. Toxicol, v. 13, n. 3, p. 253-273, 1994.

HUANG, T. F. What have snake taught us about integrins? Cell Mol. Life Sci., v. 54, p. 527-540, 1998.

HUOVILA, A.P.J.; TURNER, A.J.; HUIKKO M.P. et al. Shedding light on ADAM metalloproteinases. Trends Biochem. Sciences, v. 30, n. 7, p.413-22, July 2005.

HUMPHRIES, M. J. Integrin structure. Biochem. Soc. Trans., v. 28, n. 4, p. 311-339, 2000.

HYNES, R. O. Integrins: a family of cell surface receptors. Cell, v. 48, n.4, p. 549-554, February 1987.

HYNES, R. O. Integrins: versatility, modulation, and signaling in cell adhesion. Cell, v. 69, n. 1, p. 11-25, April 1992.

HYNES R.O.; LANDER A.D. Contact and adhesive specificities in the associations, migrations, and targeting of cells and axons. Cell, v. 68, p. 303-322, 1992.

HYNES, R.O. Targeted mutations in cell adhesion genes: what have we learned from them? Dev Biol., v. 180, n. 2, p. 402-412, 1996.

INSTITUTO BUTANTA. Animais peçonhentos: serpentes. 2007. Disponível em: $<$ http://www.butantan.gov.br/materialdidatico/numero5/numero5.htm>. Acesso em 18 de Novembro de 2007.

JUNQUEIRA-DE-AZEVEDO, I.L.M. et al. Lachesis muta (Viperidae) cDNAs reveal diverging pit viper molecules and scaffolds typical of cobra (Elapidae) venoms: implications for snake toxin repertoire evolution. Genetics Soc. of Amer., v. 173, p. 877-889, June 2006.

KANG, I.C. et al. Suppressive mechanism of salmosin, a novel disintegrin in B16 melanoma cell metastasis. Biochem. Biophys. Res. Commun., v. 275, n. 1, p. 169-173, 2000.

KOH, D. C. I., ARMUGAM, A.; JEYASEELAN, K. Review Snake venom components and their applications in biomedicine, Cell. Mol. Life Sci., v. 63, p. 3030-3041, November 2006. 
KERBEL, R.S. et al. Continuous low-dose anti-angiogenic/metronomic chemotherapy: from the research laboratory into the oncology clinic. Ann. Oncol., v. 13, p.12-15, 2002.

KIM, J. et al. Structure and function of RGD peptides derived from disintegrin proteins. Mol. Cells, v. 19, n. 2, p. 205-211, 2005.

LEE, J.Y. et al. A Disintegrin and Metalloproteinase 33 Protein in Patients with Asthma Relevance to Airflow Limitation. Am. J. Respir. Crit. Care Med., v. 173, p. 729-735, 2006.

LiOTTA, L. A.; STEEG, P. S.; STELlER-STEVENSON, W. G. Cancer metastasis and angiogenesis: an imbalance of positive and negative regulation. Cell, v. 64, p. 327-336, 1991.

LU, X. et al. Substitutions of proline 42 to alanine and methionine 46 to asparagine around the RGD domain of the neurotoxin dendroaspin alter its preferential antagonism to that resembling the disintegrin elegantin. J. Biol. Chem., v. 271, n. 1, p. 289-294, 1996.

LU, Q.; CLEMETSON, J. M.; CLEMETSON, K. J. Snake venoms and hemostasis. J. Thromb. Haemost., v.3, p. 1791-1799, 2005.

MACDONALD, T.J. et al. Phase I clinical trial of cilengitide in children with refractory brain tumors: pediatric brain tumor consortium study PBTC-012. J. Clin. Oncol., v. 26, n. 6, p. 919-924, 2008.

MARCINKIEWICZ, C. et al. Significance of RGD loop and C-terminal domain of echistatin for recognition of alphaIIb beta3 and alpha(v) beta3 integrins and expression of ligand-induced binding site. Blood, v. 90, n. 4, p. 1565-1575, 1997.

MARCINKIEWICZ, C. et al. EC3, a novel heterodimeric disintegrin from Echis carinatus venom, inhibits alpha4 and alpha5 integrins in an RGD-independent manner. J. Biol. Chem., v. 274, n. 18, p. 12468-12473, 1999a.

MARCINKIEWICZ, C. et al. Structural and functional characterization of EMF10, a heterodimeric disintegrin from Eristocophis macmahoni venom that selectively inhibits alpha 5 beta 1 integrin. Biochem., v. 38, n. 40, p. 13302-13309, 1999b.

MARCINKIEWICZ, C. et al. Obtustatin: a potent selective inhibitor of alphalbeta1 integrin in vitro and angiogenesis in vivo. Cancer Res., v. 63, p. 2020-2023, 2003.

MARCINKIEWICZ, C. Functional characterization of snake venom disintegrins: potential therapeutic implication. Curr. Pharm., v. 11, p. 815-827, 2005.

MARKLAND, F.S. Snake venoms and the hemostatic system. Toxicon, v.36, n. 12, p. 1749-1800, January 1998.

MENEZES, M.C. et al. Sex-based individual variation of snake venom proteome among eighteen Bothrops jararaca siblings. Toxicon, 2005. 
MICHISHITA, M.; VIDEM, V.; ARNAOUT, M.A. A novel divalent cation-binding site in the A domain of the beta 2 integrin CR3 (CD11b/CD18) is essential for ligand binding. Cell, v. 72, p. 857-867, 1993.

MINISTÉRIO DA SAÚDE. Manual de diagnostic e tratamento de acidentes por animais peçonhentos. 2. ed. Brasília: Fundação Nacional de Saúde. cap. 1, p. 21-24, 2001.

MINISTÉRIO DA SAÚDE. FUNDAÇÃO OSWALDO CRUZ. Animais peçonhentos e venenosos. Disponível em: <http://www.fiocruz.br/sinitox/serpentes.htm> Acesso em 04 de Novembro de 2005.

MCLANE, M. A. Viper venom disintegrins and related molecules. Proc. Soc. Exp. Biol. Med, v. 219, n. 2, p. 109-119, 1998.

NICOLAU, J.C. Diretrizes da Sociedade Brasileira de Cardiologia sobre angina instável e infarto agudo do miocárdio sem supradesnível do segmento ST. Arq. Bras. Cardiol., v. 89, n.4, 2007.

NIEWIAROWSKI, S. et al. Disintegrins and other naturally occurring antagonists of platelet fibrinogen receptors. Semin. Hematol., v. 31, n. 4, p. 289-300, 1994.

NIEWIAROWSKI, S. et al. Potential application of RGD containing peptides from viper venoms (disintegrins) in antiplatelet therapy. Thromb. Haemostasis, v. 62, n. 319, 1989.

ONDETTI, M.A.; RUBIN, B.; CUSHMAN, D.W. Design of specific inhibitors of angiotensin-converting enzyme: new class of orally active antihypertensive agents. Science, v. 196, n.4288, p. 441-444, 1977.

PINHO, F.M.O.; PEREIRA I.D. Ofidismo Rev. Ass. Med. Brasil, v. 47, n. 1, p. 24-29, 2001.

PLOW, E. F. et al. Ligand binding to integrins. J. Biol. Chem., v. 275, n. 29, p. 21785-21788, July 2000.

RAMOS, H. P. R. Desintegrinas de Bothrops alternatus: biologia molecular, estudos in vitro, in vivo e bioinformática estrutural. 2005. 252 f. Tese (Doutorado em Ciências) - Departamento de Genética e Evolução, Universidade Federal de São Carlos, 2005.

RAMOS, O.H. et al. A novel alpha(v)beta (3)-blocking disintegrin containing the RGD motive, Dis $B a-01$, inhibits bFGF-induced angiogenesis and melanoma metastasis. Clin. Exp. Metastasis., v. 25, n. 1, p.53-64, 2008 .

RUOSLAHTI, E.; PIERSCHBACHER, M. D. New perspectives in cell adhesion: RGD and integrins. Science, v. 238, p. 491-497, 1987.

RÜCKER, E. et al. Rapid evaluation and optimization of recombinant protein production using GFP tagging. Protein Expr. Purific., v. 21, p. 220-223, 2001. 
SAMBROOK, J.; RUSSEL, D.W. Molecular cloning: a laboratory manual. 3. ed. New York: Cold Spring Harbor Press, 2001.

SANCHEZ, E.F. et al. Biological activities of venoms from south american snakes. Toxicon, v.30, p.95-103, 1992.

SÁNCHEZ, E.E. et al. Isolation and characterization of two disintegrins inhibiting ADP-induced human platelet aggregation from the venom of Crotalus scutulatus scutulatus (Mohave Rattlesnake). Toxicol. Appl. Pharmacol. , v. 212 , p. $59-68,2006$.

SEALS, D.F.; COURTNEIDGE, S.A. The ADAMs family of metalloproteases: multidomain proteins with multiple functions. Genes \& Dev., v.17, p. 7-30, January, 2008.

SEITZ, R. J.; SIEBLER, M. Platelet GPIIb/IIIa Receptor Antagonists in Human Ischemic Brain Disease Vascular Pharmacol., v. 6, n. 1, p.29-36, January, 2008.

SEOW, K.T. et al. cations and the relationship between $\alpha \mathrm{A}$ and $\beta \mathrm{A}$ domains in integrins. Biochem. Pharmacol., v. 64, p. 805-812, March 2002.

SHEU, J.R. et al. Triflavin, an Arg-Gly-Asp-containing antiplatelet peptide inhibits cell-substratum adhesion and melanoma cell-induced lung colonization. Jpn. J. Cancer Res., v. 83, p. 885-893, 1992.

SHEU, J. R.; LIN, C. H.; HUAG, T. F. Triflavin, an antiplatelet peptide, inhibits tumor cell-extracellular matrix adhesion through an arginine-glycine-aspartic acid-mechanism. J. Lab. Clin. Med., v. 123, n. 2, p. 256-263, 1994.

SHEU, J. R.; HUANG, T. F. Ex-vivo and in-vivo antithrombotic effect of triflavin, an RGD-containing peptide. J. Pharm. Pharmacol., v. 46, n. 1, p. 58-62, 1994.

SHEU, J. R. et al. Triflavin, an Arg-Gly-Asp-containing peptide, prevents platelet plug formation in in vivo experiments. Eur. J. Pharmacol., v. 294, n. 1, p. 231-238, 1995.

SHIMOKAWA, K. et al. Expression, activation and processing of the recombinant snake venom metalloproteinase, Pro-Atrolysin E. Arch. Biochem. Biophys., v. 335, p. 283-294, 1996.

SHIMAOKA, M.; TAKAGI, J.; SPRINGER, T.A. Conformational regulation of integrin structure and function. Rev. Biophys. Biomol. Struct., v. 31, p. 485-516, 2002.

SMITH, K. J. et al. Three-dimensional structure of the RGD-containing snake toxin albolabrin in solution, based on 1H NMR spectroscopy and simulated annealing calculations. Int. J. Pept. Protein Res., v. 48, p. 220-228, 1996.

SOSZKA, T. et al. Inhibition of murine melanoma cell-matrix adhesion and experimental metastasis by albolabrin, an RGD-containing peptide isolated from the venom of Trimeresurus albolabris. Exp. Cell Res., v. 196, p. 6-12, 1991. 
SOUZA, D.H.F. et al. The Disintegrin-like domain of the snake venom Metalloprotease Alternagin inhibits $\alpha 2 \beta 1$ Integrin-mediated cell adhesion. Arch. Biochem. Biophys. 384, 341-350, 2000.

STAIANO, N. et al. P. Echistatin inhibits the adhesion of murine melanoma cells to extracellular matrix components. Biochem. Mol. Biol. Int., v. 35, p. 11-19, 1995.

STEVENS, R.C. Design of high-throughput methods of protein production for structural biology. Struct. Fold Des., v. 8, n.9, p. 177-185, 2000.

STUPP, R. et al. Phase I/IIa trial of cilengitide (EMD121974) and temozolomide with concomitant radiotherapy, followed by temozolomide and cilengitide maintenance therapy in patients (pts) with newly diagnosed glioblastoma (GBM). J. Clin. Oncol., v. 25, n. 18, 2007.

SWENSON, S. et al. Intravenous liposomal delivery of the snake venom disintegrin contortrostatin limits breast cancer progression. Mol. Cancer Ther., v.3, p. 499-511, 2004.

TRIKHA, M.; DE CLERCK, Y. A.; MARKLAND, F. S. Contortrostatin, a snake venom disintegrin, inhibits beta 1 integrin-mediated human metastatic melanoma cell adhesion and blocks experimental metastasis. Cancer Res., v. 54, n. 18, p. 4993-4998, 1994.

VAN-DER-FLIER, A.; SONNENBERG, A. Review Function and interactions of integrins. Cell Tissue Res., v. 305 , p. 285-298, June 2001.

XIONG, J. P. et al. Crystal structure of the extracellular segment of integrin alpha Vbeta3. Science, v. 294, n. 5541, p. 339-345, October 2001.

XIONG, J. P. et al. Crystal structure of the extracellular segment of integrin alpha Vbeta3 in complex with an Arg-Gly-Asp ligand. Science, v. 296, n. 5565, p. 151-155, April 2002.

XUE, C.-B. et al. Design, synthesis and in vitro activities of benzamide-core Glycoprotein IIb/IIIa antagonists: 2,3- diaminopropionic acid derivatives as surrogates of aspartic acid. Bioorg. Med. Chem., v. 5, n. 4, p. 693$705,1997$.

WEIBO, C.; XIAOYUAN, C. Anti-angiogenic cancer therapy based on integrin $\alpha$ V $\beta 3$ antagonism. Med. Chem., v. 6, n. 5, p. 407-428, 2007.

WIEDLE, G.; JOHNSON, L.C.; IMHOF, B.A. A chimeric cell adhesion molecule mediates homing of lymphocytes to vascularized tumors. Cancer Res., v. 59, p. 5255-5263, 1999.

WIERZBICKA-PATYNOWSKI, I. et al. Structural requirements of echistatin for the recognition of alpha(v)beta(3) and alpha(5)beta(1) integrins. J. Biol. Chem., v. 274, n. 53, p. 37809-37814, 1999.

WOLPERT, L. Princípios de Biologia de Desenvolvimento. Porto Alegre: Artes Médicas Sul. 2000. p. 10-15.

WOLFSBERG, T. G.; WHITE, J. M. Review ADAMs in fertilization and development. Dev. Biol., v. 180, n. 2, p. 389-401, 1996. 
WRIGHT, P. S. et al. An echistatin C-terminal peptide activates GPIIbIIIa binding to fibrinogen, fibronectin, vitronectin and collagen type I and type IV. Biochem. J., v. 293, p. 263-267, 1993.

YAMADA, D., SHIN, Y., MORITA, T. Nucleotide sequence of a cDNA encoding a common precursor of disintegrin flavostatin and hemorrhagic factor HR2a from the venom of Trimeresurus flavoviridis. FEBS Lett., v. 451, p. 299-302, 1999.

YAMAMOTO, M. et al. Obtaining of measles virus haemagglutinin from strain L-16 grown in primary cell cultures. Endocrinol., v. 139, p. 1411-1419, 1998.

ZETTER, B. The cellular basis of site-specific tumor metastasis. New Engl. J. Med., v. 322, n. 605, 1990.

ZHOU, Q. et al. Contortrostatin, a dimeric disintegrin from Agkistrodon contortrix contortrix, inhibits breast cancer progression. Breast Cancer Res. Treat, v. 6, p. 249-260, 2000. 